

\section{The EU in the Global Investment Regime}

The European Union (EU) has emerged as a key actor in the global investment regime since the 1980s. At the same time, international investment policy and agreements, which govern international investment liberalisation, treatment and protection through investor-to-state dispute settlement, have become increasingly contentious in the European public debate.

This book provides an accessible introduction to international investment policy and seeks to explain how the EU became an actor in the global investment regime. It offers a detailed analysis of the EU's participation in all major trade and investment negotiations since the 1980s and EU-internal competence debates to identify the causes behind the EU's growing role in this policy domain. Building on principal-agent and historical institutionalist models of incremental institutional change, the book shows that Commission entrepreneurship was instrumental in the emergence of the EU as a key actor in the global investment regime. It refutes business-centred liberal intergovernmental explanations, which suggest that business lobbying made the Member States accept the EU's growing role and competence in this domain. The book lends support to supranational and challenges intergovernmental thinking on European Integration.

This text will be of key interest to scholars, students and practitioners of European and regional integration, EU foreign relations, EU trade and international investment law, business lobbying, and more broadly to international political economy.

Johann Robert Basedow is a Visiting Fellow at the European University Institute in Florence, Italy, and an Assistant Professor in International Political Economy at the London School of Economics, United Kingdom. 


\section{Routledge/UACES Contemporary European Studies}

Edited by Chad Damro

University of Edinburgh, United Kingdom

Elaine Fahey

City University London, United Kingdom

David Howarth

University of Luxembourg, Luxembourg, on behalf of the University Association for Contemporary European Studies

Editorial Board: Grainne De Búrca, European University Institute and Columbia University; Andreas Føllesdal, Norwegian Centre for Human Rights, University of Oslo; Peter Holmes, University of Sussex; Liesbet Hooghe, University of North Carolina at Chapel Hill, and Vrije Universiteit Amsterdam; David Phinnemore, Queen's University Belfast; Ben Rosamond, University of Warwick; Vivien Ann Schmidt, University of Boston; Jo Shaw, University of Edinburgh; Mike Smith, University of Loughborough and Loukas Tsoukalis, ELIAMEP, University of Athens and European University Institute.

The primary objective of the new Contemporary European Studies series is to provide a research outlet for scholars of European Studies from all disciplines. The series publishes important scholarly works and aims to forge for itself an international reputation.

For more information about this series, please visit: www.routledge.com/ Routledge-UACES-Contemporary-European-Studies/book-series/UACES

33 Russia's Impact on EU Policy Transfer to the Post-Soviet Space The contested neighbourhood Esther Ademmer

34 Domestic Politics and Norm Diffusion in International Relations Ideas do not float freely

Thomas Risse

35 Euroscepticism as a Transnational and Pan-European Phenomenon The emergence of a new sphere of opposition Edited by John FitzGibbon, Benjamin Leruth and Nick Startin

36 Global Power Transition and the Future of the European Union Birol A. Yeşilada, Jacek Kugler, Gaspare Genna and Osman Göktuğ Tanrıkulu

37 The EU in the Global Investment Regime

Commission Entrepreneurship, Incremental Institutional Change

and Business Lethargy

Johann Robert Basedow 


\section{The EU in the Global Investment Regime \\ Commission Entrepreneurship, Incremental Institutional Change and Business Lethargy}

\section{Johann Robert Basedow}


First published 2018

by Routledge

2 Park Square, Milton Park, Abingdon, Oxon OX14 4RN

and by Routledge

711 Third Avenue, New York, NY 10017

Routledge is an imprint of the Taylor \& Francis Group, an informa business

(C) 2018 Johann Robert Basedow

The right of Johann Robert Basedow to be identified as author of this work has been asserted by him in accordance with sections 77 and 78 of the Copyright, Designs and Patents Act 1988.

All rights reserved. No part of this book may be reprinted or reproduced or utilised in any form or by any electronic, mechanical, or other means, now known or hereafter invented, including photocopying and recording, or in any information storage or retrieval system, without permission in writing from the publishers.

Trademark notice: Product or corporate names may be trademarks or registered trademarks, and are used only for identification and explanation without intent to infringe.

\section{British Library Cataloguing-in-Publication Data}

A catalogue record for this book is available from the British Library

Library of Congress Cataloging-in-Publication Data

Names: Basedow, Johann Robert, author.

Title: The EU in the global investment regime commission : entrepreneurship, incremental institutional change and business lethargy / Johann Robert Basedow.

Description: Abingdon, Oxon ; New York, NY : Routledge, 2018. | Series: Routledge/UACES contemporary European studies ; 37 | Includes bibliographical references and index.

Identifiers: LCCN 2017032315 | ISBN 9781138083370 (hardback) | ISBN 9781315112282 (ebook)

Subjects: LCSH: Investments, Foreign-European Union countries. | Investments, Foreign - Law and legislation-European Union countries. | European Union countries-Commercial policy.

Classification: LCC HG5422 .B37 2018 | DDC 332.67/3094—dc23

LC record available at https://lccn.loc.gov/2017032315

ISBN: 978-1-138-08337-0 (hbk)

ISBN: 978-1-315-11228-2 (ebk)

Typeset in Times New Roman

by Apex CoVantage, LLC 
To my parents 
$\because$ Taylor \& Francis

Taylor \& Francis Group

http://taylorandfrancis.com 


\section{Contents}

List of figures $\quad$ ix

List of tables $\quad \mathrm{x}$

List of boxes $\quad$ xi

Preface xii

List of abbreviations $\quad$ xiii

1 Introduction 1

2 European integration theory and the EU's new international investment policy

3 An introduction to international investment and its regime 46

4 An overview of EU international investment policymaking under the Treaty of Lisbon

5 The EU in investment-related negotiations during the Uruguay Round

6 The EU in investment-related negotiations on the Energy Charter Treaty

7 The EU in negotiations on the multilateral agreement on investment and the Singapore Issues

8 Investment disciplines in European Preferential Trade Agreements 
viii Contents

9 The evolution of the EU's legal competences in international investment policy

10 Conclusion

Index 


\section{Figures}

1.1 A chronology of the emergence of the EU's international investment policy (1980-2017)

2.1 A three-stage model of commission entrepreneurship for institutional change

2.2 Simplified causal relationship as described in liberal intergovernmentalism

2.3 Member states' outward FDI stocks of EU total (2014)

2.4 Extra-EU outward FDI stocks by sector (2014)

3.1 Number of ratified BITs of leading capital-exporting countries (1958-2012)

3.2 World inward FDI stock in trillion US dollars (1980-2012) 


\section{Tables}

2.1 Identifying conceptual overlaps between historical institutionalism and principal-agent research

2.2 Share of selected Member States in outward FDI and number of ratified BITs (2017)

3.1 Overview of OLI framework

7.1 Number of meetings and submissions per year by country (selection)

10.1 Summary of empirical observations 


\section{Boxes}

$\begin{array}{lll}2.1 & \text { Economic and policy entrepreneurs } & 17\end{array}$

2.2 Institutionalism in a nutshell 18

2.3 Who are the stakeholders in the EU's international investment policy? 


\section{Preface}

This book traces and seeks to explain the EU's growing role in international investment policy and the global investment regime from the 1950s until 2017. It has benefited from the support and input of many people and institutions. I am particularly indebted to my $\mathrm{PhD}$ supervisor Stephen Woolcock for his guidance. I am grateful for critical and helpful feedback on the various drafts and elements of this book manuscript by Cornelia Woll, Angelos Dimopoulos and Bernard Hoekman. My research and the book manuscript have also benefited from the stimulating intellectual environments at the London School of Economics, the European University Institute, the Directorate General for Trade of the European Commission and the Organisation for Economic Co-operation and Development (OECD). I have discussed my research with many knowledgeable colleagues in these places, which has significantly helped me in developing and refining my thinking. Last but not least, I am deeply thankful for the support of my family and in particular of my parents. I dedicate this book to them.

All errors remain mine. 


\section{Abbreviations}

\begin{tabular}{ll} 
ACP & African, Caribbean and Pacific Group of States \\
BDI & Bundesverband der Deutschen Industrie \\
BIAC & Business and Industry Advsisory Committee \\
BIT & Bilateral Investment Treaty \\
CCP & Common Commercial Policy \\
CEFIC & European Chemical Industry Council \\
CEOE & Confederación Española de Organizaciones Empresariales \\
CETA & Comprehensive Economic and Trade Agreement \\
CIL & Customary International Law \\
CIME & Committee on Multinational Enterprise \\
CIS & Community of Independent States \\
CJEU & Court of Justice of the European Union \\
CMIT & Committee on Capital Movements and Invisible Transactions \\
Confindustria & Confederazione Generale dell'Industria Italiana \\
DIHK & Deutscher Industrie- und Handelskammertag \\
DG & Directorate General \\
ECFIN & Economic and Financial Affairs \\
ECJ & European Court of Justice (see CJEU) \\
ECSG & European Communities Services Group \\
ECT & Energy Charter Treaty \\
ESF & European Services Forum \\
EU & European Union \\
EUSFTA & European Union-Singapore Free Trade Agreement \\
FCN & Treaties of Friendship, Commerce and Navigation \\
FDI & Foreign Direct Investment \\
FET & Fair and Equitable Treatment \\
FPS & Full Protection and Security \\
FTA & Free Trade Agreement \\
GATS & General Agreement on Trade in Services \\
GATT & General Agreement on Tariffs and Trade \\
GNS & Group for Negotiations on Services \\
ICSID & International Centre for Settlement of Investment Disputes \\
& \\
\hline
\end{tabular}


IGC Intergovernmental Conference

IIA International Investment Agreement

IMF International Monetary Fund

IPE International Political Economy

IR International Relations

ISDS Investor-to-State Dispute Settlement

MAI Multilateral Agreement on Investment

MEDEF Mouvement des Entreprises de France

Mercosur Mercado Común del Sur

MFN Most-Favoured Nation

MNE Multinational Enterprise

MPoI Minimal Platform on Investment

NAFTA North American Free Trade Agreement

NT National Treatment

OECD Organisation for Economic Co-operation and Development

OLI Ownership-, Location-, Internalisation-specific advantages

R\&D Research and Development

Relex External Relations

REIO Regional Economic Integration Organisation

SFSRs Soviet Federal Socialist Republics

SWF Sovereign Wealth Fund

EC Treaty establishing the European Communities

TEN-E Trans-European Energy Networks Initiative

TFEU Treaty on the Functioning of the European Union

TPA Third Party Access

TPC Trade Policy Committee ('113 Committee', '133 Committee')

TPP Transpacific Partnership

TRIMs Trade-Related Investment Measures

TRIPs Trade-Related Intellectual Property

TTIP Transatlantic Trade and Investment Partnership

TUAC Trade Union Advisory Committee

UNCITRAL United Nations Committee on International Trade Law

UNCTAD United Nations Committee on Trade and Development

UNICE Union des Industries de la Communauté Européenne

WTO World Trade Organisation 


\section{Introduction}

In June 2010, the European Commission published a communication and draft regulation dealing with international investment regulation (European Commission, 2010a, 2010b). The communication, entitled Towards a Comprehensive European International Investment Policy, underlined that the Treaty of Lisbon (2009) had extended the scope of the Common Commercial Policy (CCP) to the regulation of Foreign Direct Investment (FDI). The EU had thus undeniably become a key actor in the global investment regime. The communication discussed how the Commission envisaged using the European Union's (EU) ${ }^{1}$ new exclusive competence in international investment policy to the benefit of Europe. The draft regulation, on the other hand, discussed how to deal with the Member States' regulatory legacy in the form of some 1,300 bilateral investment treaties (BITs). It proposed to review all Member State BITs in view of their legality and conformity to European law and policy objectives.

While the two documents were hardly spectacular in purpose and content, they stirred furore among investment policy officials of the Member States. National investment policy officials, it seemed, had so far lived in denial, or indeed not known about the new legal situation. During the following months, national investment policy officials publically accused the Commission of having surreptitiously usurped the competence to regulate international investment flows. They pointed out that many Member States had clearly opposed the extension of the CCP to FDI regulation during the relevant debates in the Convention on the Future of Europe (2002/2003) and the following Intergovernmental Conferences (IGCs) on the Constitutional and Lisbon Treaties. They, moreover, warned that the Commission lacked the necessary expertise to adequately represent and defend European interests in the international investment regime. They pointed to the Commission's draft regulation on how to deal with existing Member State BITs as an example of the Commission's technical incompetence and disregard for the needs of European investors. They claimed that the proposed review process for Member State BITs would create legal uncertainty for European investors and thereby hinder investment activity. Some Member States such as Germany, France and the United Kingdom, furthermore, continued negotiating and signing BITs with third countries despite being arguably in breach of European law (UNCTAD, 2017). The atmosphere between the Commission and the relevant national ministries 


\section{Introduction}

was extraordinarily tense at this time. And only in May 2017 - eight years after the entry into force of the Treaty of Lisbon and in the midst of finalising this book manuscript - did the Court of Justice of the European Union (CJEU) finally resolve the simmering competence dispute between the Commission and the Member States. In Opinion 2/15 (European Court of Justice, 2017), the CJEU clarified that the EU indeed largely holds the exclusive competence to enter into international agreements dealing with market access, post-establishment treatment and protection of FDI.

The Member States' opposition to the extension of the CCP to FDI regulation is remarkable in the global scheme of things. It stands in contrast to the Member States' previous behaviour in this policy domain, as they had temporarily empowered the EU on several occasions to participate in international investment negotiations since the $1980 \mathrm{~s}$. The Commission represented the Member States, for instance, in investment-related negotiations during the Uruguay Round of the General Agreement on Trade and Tariffs (GATT) and in the Doha Round of the World Trade Organisation (WTO). The Commission was also deeply involved in the most ambitious modern investment negotiations on the Energy Charter Treaty (ECT) and the Multilateral Agreement on Investment (MAI). Since the late 1990s, the Member States even empowered the Commission to seek the inclusion of investment provisions into European Free Trade Agreements (FTAs). Hence, the EU has been playing an increasingly central role and acquiring so-called de facto competences in international investment policy since the $1980 \mathrm{~s}$. The term 'de facto competences' refers to the Member States agreeing on informal policymaking rules to jointly govern policy issues predominantly coming under Member State competences. De facto competences are thus tantamount to an informal 'Brusselisation' of policymaking (Woolcock, 2011, pp. 33-34).

The preceding discussion draws a conflicting and intriguing picture of the EU's involvement in international investment regulation. The Member States, on the one hand, cooperated and temporarily empowered the EU to participate in major international investment negotiations. But on the other hand, the Member States - ultimately unsuccessfully - opposed the extension of the EU's legal competences in this key domain of global economic governance. On the whole, these observations seem counterintuitive and inconsistent with mainstream theories of the fields of European Integration and International Relations and trigger several questions. Why did Member States readily cooperate and empower the EU to participate in international investment negotiations since the 1980s? And why did Member States then oppose the extension of the EU's legal competences in this domain? And, finally, why did the Lisbon Treaty extend the EU's exclusive competence to FDI regulation despite the reported opposition from Member States? Existing research on the EU's involvement in international investment policy is scarce (Billiet, 2006; Meunier, 2017; Niemann, 2013; Young, 2001). The few existing studies neither provide exhaustive theoretical nor empirical accounts. This book closes this research gap. The objective is to trace and to explain the emergence of the EU's international investment policy from the EU's first involvement in the global investment regime in the 1980s until the entry into 
force of the Treaty of Lisbon and the extension of the CCP to FDI regulation in 2009. The overarching research question of the book thus reads as follows: Why has the EU acquired de facto and legal competences to regulate international investment flows since the 1980s?

\subsection{The argument in a nutshell}

The book argues that Commission entrepreneurship was the main driver behind the emergence of the EU's international investment policy. The book builds on principal-agent models and historical institutionalism to develop the argument. Principal-agent models help us understand why and how the Commission could acquire a central role in international investment negotiations since the $1980 \mathrm{~s}$ despite the EU's limited competences and Member State hesitation (Da Conceição, 2010; da Conceição-Heldt and Meunier, 2014; Kerremans, 2004; Meunier, 2005; Pollack, 2003; Schmidt, 1998; Young, 2001). The Commission used its agency autonomy - for instance through agenda setting, the invoking of fringe and implied competences or international forum shopping - to consolidate its role in international investment negotiations. Historical institutionalism, in turn, offers a promising framework to explain how the EU's growing role in international investment negotiations affected formal integration and led to a comprehensive competence transfer under the Treaty of Lisbon (Büthe, 2016; Mahoney and Thelen, 2010; Stacey and Rittberger, 2003; Streeck and Thelen, 2005). Seen through a historical institutionalist lens, the Commission's short-term strategies to consolidate its role in international investment negotiations amounted to incremental agencydriven institutional change in the form of 'conversion' (re-interpretation of existing institutional rules), 'layering' (adding of new subordinate institutional rules) and 'drift' (change in the policy environment altering the effect of institutions). The Commission promoted for instance 'conversion' by invoking implied and fringe competences from adjacent policy domains to ensure its involvement in investment negotiations. The Commission, moreover, engaged in 'layering' when it had recourse to the CJEU to clarify the EU's legal competences and pushed for - at first sight - unrelated treaty changes to consolidate the EU's role in investment policy. Finally, the Commission fuelled institutional 'drift' when it pushed investment negotiations into policy fora such as the WTO or bilateral trade negotiations, where the EU conventionally speaks through the Commission with a single voice regardless of competence issues. The Commission's efforts gradually consolidated the EU's accepted role, extended relevant legal competences and ultimately reconfigured the preferences of key policymakers in favour of a comprehensive competences transfer. The combination of principal-agent models and historical institutionalism thus offers an illuminating analytical framework to understand how Commission autonomy and entrepreneurship in daily policymaking affect long-term formal integration.

The book, moreover, argues that business preferences and lobbying cannot account for the emergence of the EU's international investment policy. It is widely assumed that European business preferences and lobbying decisively shape 
international investment policy and may account for the EU's growing role in this domain. The assumption builds on the intuitive reasoning that business is arguably the main stakeholder of international investment policy and should shape policy outcomes to maximise profits. With regard to the emergence of the EU's international investment policy, it is occasionally suggested that growing global competition over lucrative investment opportunities motivated European business to push for a communitarisation of international investment policymaking to maximise bargaining power in international negotiations. This reasoning, which reflects liberal intergovernmental thinking (Moravcsik, 1998), is flawed in two regards. First and foremost, businesses rarely take an interest in international investment policy. International investment policy and agreements - apart from investment liberalisation commitments - have minor, distant and uncertain economic effects on business operations and profits. International investment agreements (IIAs) seek to ensure a minimum level of investor treatment and protection abroad through access to investment arbitration. Businesses investing abroad, however, often discount or internalise the risk of future expropriation, are hesitant to use investment arbitration in case of a dispute with a host country and finally cannot know whether they might win an arbitration case. Investors have won not even a third of known investment arbitration proceedings (UNCTAD, 2014a, p. 10). Businesses thus perceive the benefits of pushing for IIAs as minor, uncertain and distant, while the costs of forming preferences and lobbying policymakers are immediate and substantial. The political economy of international investment policy thus differs significantly from classic trade policy, which redistributes welfare within society through market liberalisation/protection and thereby triggers forceful lobbying (Hiscox, 2002; Krugman et al., 2014; Milner, 1999; Rogowski, 1989; Viner, 1950). More importantly for this study, businesses presumably would only take an interest and lobby for changing the institutional setup of international investment policymaking within the EU, if it affects policy substance and alters the earlier identified economic effects on businesses. The communitarisation of international investment policy, however, is unlikely to have such effects. While it has for instance been argued that the integration of international investment policy increases Europe's bargaining power in international investment policy, it is important to note that IIAs have always been fairly standardised and are becoming even more similar in content (Alschner, 2013; Alvarez, 2009; Dolzer and Schreuer, 2012; Mills, 2011; Salacuse, 2010). Bargaining power is of limited importance in international investment negotiations. It follows that European business should not have held strong preferences or lobbied for the integration of international investment policy.

The book empirically confirms the twofold argument through qualitative in-depth case studies, analysing all concluded international investment negotiations since the 1980s, where the EU participated despite missing legal competences. It focuses on investment-related negotiations during the Uruguay Round (1986-1994); the negotiations on the ECT (1990-1998); the failed negotiations on the MAI at the OECD (1995-1998); the short-lived investment negotiations of the Doha Round; and finally negotiations with Mexico and Chile on the EU's first comprehensive preferential trade agreements (PTAs) to encompass investment provisions (19972003) (Figure 1.1). The book assesses for each case study why the EU was allowed 


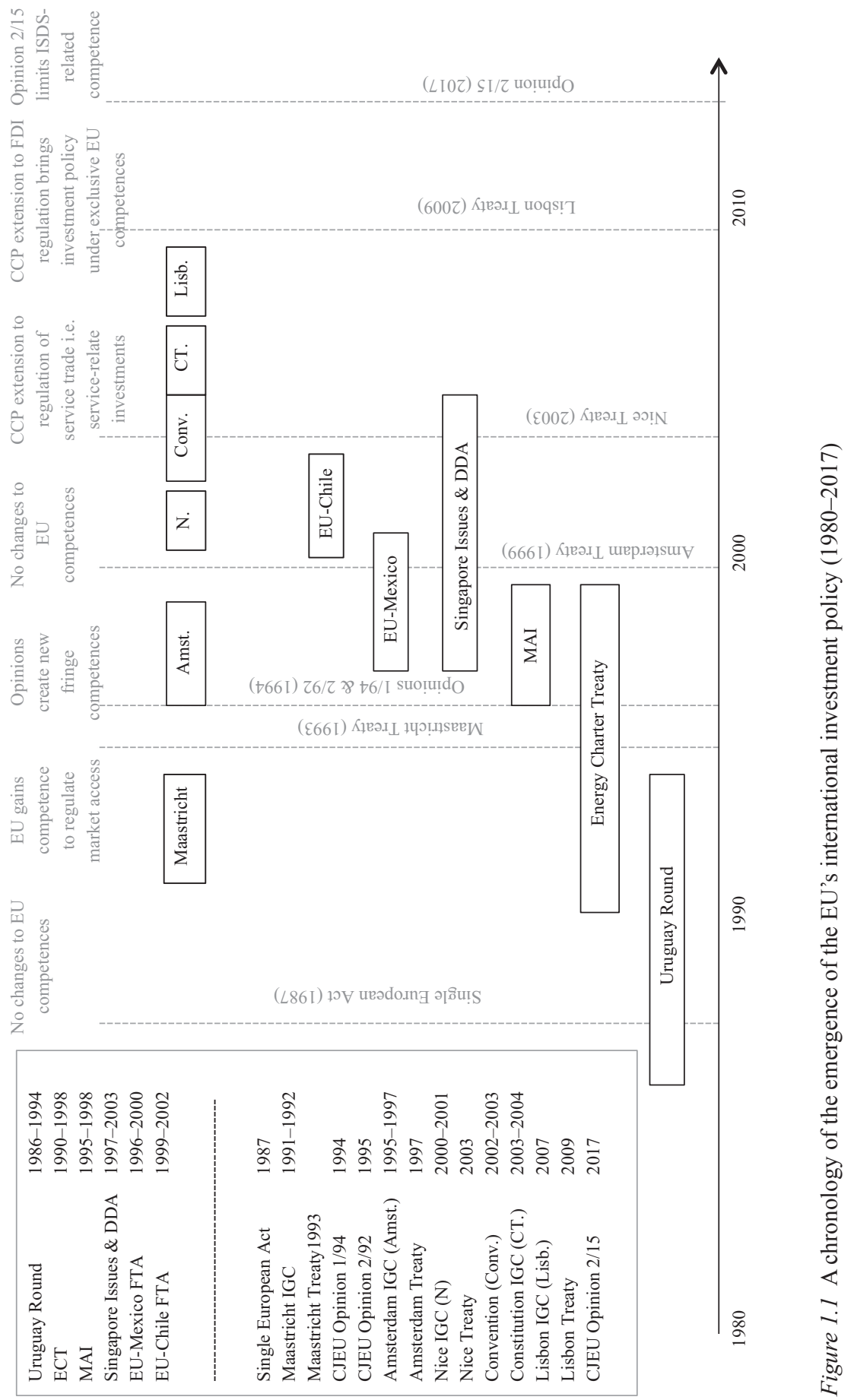




\section{Introduction}

to participate in the first place; and what actors and factors shaped the EU's engagement in these fora. Turning to the evolution of the EU's legal competences, the book assesses the long-standing discussions between the Member States and the Commission over the EU's role in international investment regulation as part of IGCs and CJEU proceedings. The assessment covers an extensive time period between the 1950s and 2017. It builds on 42 anonymised interviews with policymakers and business leaders, press and archival research, primary documents and secondary literature.

\subsection{Theoretical, empirical and policy contributions}

The contributions of this book are of empirical, theoretical and policy nature. First and foremost, it closes an empirical gap in the literature and covers in detail the EU's role in the global investment regime and underlying integration dynamics. Political scientists have only in passing, and for short policymaking instances, assessed the EU's role in international investment policy (Billiet, 2006; Manger, 2009; Meunier, 2017; Niemann, 2013; Young, 2001). These studies do not offer a comprehensive empirical or analytical picture of the EU's role in the global investment regime. Legal scholars, on the other hand, have paid significantly more attention to the EU's role in international investment regulation (Baetens, 2015; Bischoff, 2011; Dimopoulos, 2011; Eilmansberger, 2009; Hoffmeister and Ünüvar, 2012; Kleinheisterkamp, 2014; Poulsen et al., 2015; Reinisch, 2013). They focus, however, on legal questions and do not explain the EU's growing role in this policy domain.

The book, moreover, makes three theoretical contributions. First, it develops an innovative model of Commission entrepreneurship based on principal-agent models and historical institutionalism. It theoretically links the Commission's influence on daily policymaking to long-term, incremental institutional change. In other words, it conceptually connects informal integration in daily policymaking to formal integration through treaty revisions. The book thus breaks with an established research tradition in European studies. Many studies either assess daily policymaking; or analyse intergovernmental negotiations on treaty revisions (Moravcsik, 1998; Pollack, 2003; Rosamond, 2000). The analytical separation of informal and formal integration allows for theoretical parsimony. Informal integration and daily policymaking are subject to different dynamics than formal integration through IGC and treaty revisions. The differences between informal and formal integration create 'noise' hindering the development of theoretically elegant explanations. The drawback of this research approach, however, is that informal and formal integration are often interconnected and mutually condition each other (Bickerton et al., 2015; Büthe, 2016; Pierson, 1994, 2004). In foreign economic policy, informal integration in the form of ad hoc cooperation and delegation typically precede formal integration through treaty revisions (Elsig, 2002; Niemann, 2013). Formal integration indeed is often the outcome of prior informal integration. It is crucial to 
understand the drivers of informal integration to explain formal integration in this policy domain. This rationale informs the research design and analytical framework developed in Chapter 2.

This book's second theoretical contribution relates to liberal intergovernmental thinking. It challenges liberal intergovernmentalism in two regards (Börzel, 2013; Moravcsik, 1998; Moravcsik and Schimmelfennig, 2009; Rosamond, 2000; Wiener, 2009). First, liberal intergovernmentalism views integration as only occurring if (major) Member States benefit and push for it. The book makes the empirical and theoretical argument that European Integration occurred in international investment policy despite hesitation by (major) Member States. Second, liberal intergovernmentalism assumes that business preferences and lobbying decisively shape Member State preferences and ultimately European Integration outcomes. Business was mostly disengaged from international investment policy and held no strong preferences regarding the institutional setup of international investment policymaking in the complex multilevel governance system of the EU. Indeed, in many cases, the institutional policymaking setup has only limited complex substantive implications and economic effects on businesses. Businesses thus face weak incentives to invest resources in costly preference formation and lobbying. Hence, it may be necessary to reconsider the role of business preferences and lobbying in liberal intergovernmentalism. Business preferences and lobbying may be an important driver with regard to policies related to the development of the Single Market and with direct implications for business operations and profits, but policies which are more removed from markets and daily business operations are unlikely to be subject to strong business preferences and lobbying.

This book's third theoretical contribution relates to societal theories of foreign economic policy. This book scrutinises the burgeoning literature on business preferences and lobbying patterns (Dür, 2008; Eckhardt, 2015; Frieden, 1991; Grossmann and Helpman, 1995; Hiscox, 2002; Krugman et al., 2014; Rogowski, 1989; Woll, 2008; Woll and Artigas, 2007). Studies argue that businesses form preferences as a function of the expected impacts of foreign economic policies on profits. Businesses would consequently lobby policymakers for profit-maximising options. To determine the impacts of foreign economic policies on business profits, most studies build on Vinerian economics. Liberal foreign economic policies should increase the profits of export-competing firms and sectors, whereas protectionist foreign economic policies should benefit import-competing firms and sectors. However, foreign economic policy - and international trade - have evolved significantly during the last decades (Eckhardt, 2015; Young, 2016). In the past, foreign economic policy dealt with classic on-the-border market access barriers such as tariffs and quotas. The imposition or removal of these barriers had direct and well-understood effects on import and export competition and business profits. The formation of business preferences and lobbying patterns were therefore straightforward. Nowadays, foreign economic policy increasingly focuses on 


\section{Introduction}

complex regulatory issues. It seeks to remove regulatory hurdles and frictions through various instruments of regulatory cooperation and harmonisation (Basedow and Kauffmann, 2016; OECD, 2017). IIAs, for instance, seek to create a minimum level of property protection across borders. The rise of regulatory foreign economic policy has two distinct effects on the formation of business preferences and lobbying patterns. First, regulatory foreign economic policy may have only limited and distant economic effects on business operations and profits. Businesses, therefore, may face weak incentives to form preferences and to lobby for specific policy outcomes. Second, businesses may struggle to understand whether and how complex regulatory foreign economic policy measures affect their operations and profits, and therefore whether they should lobby policymakers. The empirical chapters of this book produce ample evidence of such complexity-induced business lethargy. Preference formation and lobbying have become more complex and difficult to model. This development may increase the causal importance of trade bureaucrats in policy outcomes. They provide businesses with initial information and explanation of policies and thereby shape business perceptions, preferences and lobbying (Woll, 2008; Woll and Artigas, 2007). To conclude, additional research on the formation of business preferences and lobbying patterns in modern regulatory foreign economic policy is needed.

Finally, the book makes a policy contribution. It ties in with debates on reforming IIAs and investor-to-state dispute settlement. Its findings imply that states may strengthen states' right to regulate under IIAs without risking a significant decline in international investment activities and related economic opportunity costs. Many policymakers, media, non-governmental organisations and citizens increasingly worry that IIAs and traditional investor-to-state dispute settlement mechanisms overly constrain states' right to regulate and impose potentially significant financial risks on taxpayers. Demands to reform IIAs and investor-tostate dispute settlement are multiplying (Baetens, 2015; Mestral and Lévesque, 2013; Poulsen et al., 2015). Many proposals foresee more precise language on treatment and protection standards, higher hurdles for the launch of investment arbitration and more transparent arbitration proceedings. Critics have warned that such proposals undermine investment protection and ultimately lead to a decline in international investment activities, foregone growth and development opportunities (Lavranos, 2013; Peterson, 2011; Reinisch, 2013). The findings of the book show that European business rarely takes an interest in international investment policy. Economic research on the impact - or rather non-impact - of IIAs on investment decisions and flows by and large confirms these findings (Blonigen and Piger, 2014; Busse et al., 2010; Colen et al., 2014; Egger and Merlo, 2007; Hallward-Driemeier, 2003; Neumayer and Spess, 2005; UNCTAD, 2014b). Most European businesses seem little aware and knowledgeable of international investment policy. It seems unlikely that European businesses would react to a reform of IIAs by reducing their international investment activities. The costs of reforming IIAs may thus be lower than suggested in the policy debate. 


\subsection{The structure of the book}

The book is structured as follows. Chapter 2 develops in detail the theoretical argument and lays the analytical-theoretical foundations for the empirical chapters. Chapter 3 introduces the non-expert reader to international investment and its regime. It defines international investment, discusses economic and political impacts of international investment activities on home and host economies, and identifies the tools and purposes of international investment policy and its historical roots. Chapter 4 provides an overview of the EU's legal competences in international investment policy and identifies the key actors and their preferences in international investment policy. Chapter 5 turns to the empirical analysis and examines the EU's involvement in investment-related negotiations during the Uruguay Round of the GATT (1986-1994). Chapter 6 shifts the analytical focus to the EU's role in investment-related negotiations on the ECT (1990-1998). Chapter 7 analyses the EU's participation in the MAI negotiations (1995-1998) and the closely related but short-lived investment negotiations as part of the Singapore Issues in the Doha Round (1996-2003). Chapter 8 examines how investment provisions made their way into European FTAs. The focus lies on the EU-Mexico negotiations (1996-1999) and EU-Chile negotiations (1999-2002), which marked the beginning of investment provisions in European PTAs. Chapter 9 examines the EU-internal debates during legal proceedings, IGCs and the Convention on the Future of Europe, which shaped the EU's legal competences. Chapter 10 concludes and discusses the empirical findings and theoretical implications of this study.

\section{Note}

1 For the sake of simplicity this book uses the term European Union/EU in order to refer to precursor organisations like the European Economic Communities (EEC) or the European Communities (EC). It does not assume that these organisations had the same political, economic and legal properties as today's EU.

\section{References}

Alschner, W., 2013. Americanization of the BIT universe: The influence of Friendship, Commerce and Navigation (FCN) treaties on modern investment treaty law. Goettingen J. Int. Law 5, 455-486.

Alvarez, J.E., 2009. The Public International Law Regime governing international investment, Recueil de cours of the Hague Academy of International Law. Martinus Nijhoff Publishers, Leiden.

Baetens, F., 2015. Transatlantic investment treaty protection: A response to Poulsen, Bonnitch a and Yackee, CEPS Special Report. CEPS, Brussels.

Basedow, R., Kauffmann, C., 2016. International trade and good regulatory practices: Assessing the trade impacts of regulation. OECD Regul. Policy Work. Pap. 4.

Bickerton, C., Hodson, D., Puetter, U., 2015. The new intergovernmentalism: European integration in the post-maastricht era. J. Common Mark. Stud. 53, 703-722.

Billiet, S., 2006. From GATT to the WTO: The internal struggle for external competences in the EU. J. Common Mark. Stud. 44, 899-919. 


\section{Introduction}

Bischoff, J.A., 2011. Just a little BIT of 'mixity'? The EU's role in the field of international investment protection law. Common Mark. Law Rev. 48, 1527-1570.

Blonigen, B.A., Piger, J., 2014. Determinants of foreign direct investment. Can. J. Econ. 47, 775-812. doi:10.1111/caje.12091

Börzel, T., 2013. Comparative regionalism: European integration and beyond, in: Carlsnaes, W., Risse, T., Simmons, B. (Eds.), Handbook of international relations. Sage, London, pp. 501-530.

Busse, M., Königer, J., Nunnenkamp, P., 2010. FDI promotion through bilateral investment treaties: More than a bit? Rev. World Econ. 146, 147-177. doi:10.1007/ s10290-009-0046-X

Büthe, T., 2016. Historical institutionalism and institutional development in the EU: The development of supranational authority over government subsidies (State Aid), in: Rixen, T., Viola, L.A., Zürn, M. (Eds.), Historical institutionalism and international relations: Explaining institutional development in world politics. Oxford University Press, Oxford, pp. 37-66.

Colen, L., Persyn, D., Guariso, A., 2014. What type of FDI is attracted by bilateral investment treaties? LICOS Discuss. Pap. 346/2014.

Da Conceição, E., 2010. Who controls whom? Dynamics of power delegation and agency losses in EU trade politics. JCMS J. Common Mark. Stud. 48, 1107-1126.

Da Conceição-Heldt, E., Meunier, S., 2014. Speaking with a single voice: Internal cohesiveness and external effectiveness of the EU in global governance. J. Eur. Public Policy 21, 961-979.

Dimopoulos, A., 2011. EU foreign investment law. Oxford University Press, Oxford.

Dolzer, R., Schreuer, C., 2012. Principles of international investment law, 2nd ed. Oxford University Press, Oxford.

Dür, A., 2008. Bringing economic interests back into the study of EU trade policy-making. Br. J. Polit. Int. Relat. 10, 27-45.

Eckhardt, J., 2015. Business lobbying and trade governance. Palgrave Macmillan, Basingstoke.

Egger, P., Merlo, V., 2007. The impact of bilateral investment treaties on FDI dynamics. World Econ. 30, 1536-1549.

Eilmansberger, T., 2009. Bilateral investment treaties and EU law. Common Mark. Law Rev. 46, 383-429.

Elsig, M., 2002. The EU's common commercial policy: Institutions, interests and ideas. Ashgate, London.

European Commission, 2010a. Proposal for a regulation of the European Parliament and the Council establishing transitional arrangements for bilateral investment agreements between Member States and third countries (COM(2010) 344 final). Brussels.

European Commission, 2010b. Towards a comprehensive European international investment policy (COM(2010)343). Brussels.

European Court of Justice, 2017. Opinion 2/15 (ECLI/EU/C/2017/376). Luxemburg.

Frieden, J., 1991. Invested interests: The politics of national economic policies in a world of global finance. Int. Organ. 45, 425-451.

Grossmann, G., Helpman, E., 1995. The politics of free trade agreements. Am. Econ. Rev. 85, 667-690.

Hallward-Driemeier, M., 2003. Do bilateral investment treaties attract foreign direct investment? Only a bit? and they could bite, policy research working papers. The World Bank. doi:10.1596/1813-9450-3121

Hiscox, M., 2002. International trade and political conflict: Commerce, coalitions, and mobility. Princeton University Press, Princeton. 
Hoffmeister, F., Ünüvar, G., 2012. From BITS and Pieces towards European investment agreements. Presented at the EU and Investment Agreements, Vienna.

Kerremans, B., 2004. What went wrong in Cancún? A principal-agent view of the EU's rationale towards the Doha Development Round. Eur. Foreign Aff. Rev. 9, 363-393.

Kleinheisterkamp, J., 2014. Financial responsibility in European international investment policy. Int. Comp. Law Q. 63, 449-476. doi:10.1017/S0020589314000116

Krugman, P., Obstfeld, M., Melitz, M., 2014. International trade: Theory and policy: Global edition, 10th ed. Pearson, New York.

Lavranos, N., 2013. The new EU Investment Treaties: Convergence towards the NAFTA model as the new Plurilateral Model BIT text? Vrije Universiteit Brussel. URL https:// cris.cumulus.vub.ac.be/portal/files/29952551/SSRN_id2241455.pdf

Mahoney, J., Thelen, K. (Eds.), 2010. Explaining institutional change: Ambiguity, agency, and power, 1st ed. Cambridge University Press, Cambridge.

Manger, M., 2009. Investing in protection: The politics of preferential trade agreements between north and south. Cambridge University Press, Cambridge.

Mestral, A.L.C.D., Lévesque, C., 2013. Improving international investment agreements. Routledge, London.

Meunier, S., 2017. Integration by stealth: How the European Union gained competence over foreign direct investment. J. Common Mark. Stud. 1-18.

Meunier, S., 2005. Trading voices: The European Union in international commercial negotiations. Princeton University Press, Princeton.

Mills, A., 2011. Antinomies of public and private at the foundations of international investment law and arbitration. J. Int. Econ. Law 14, 469-503.

Milner, H., 1999. The political economy of international trade. Annu. Rev. Polit. Sci. 2 , 91-114.

Moravcsik, A., 1998. The choice for Europe: Social purpose and state power from Messina to Maastricht. Cornell Univeristy Press, Ithaca.

Moravcsik, A., Schimmelfennig, F., 2009. European Integration Theory. Liberal intergovernmentalism, in: Wiener, A., Diez, T. (Eds.). Oxford University Press, Oxford, pp. 67-87.

Neumayer, E., Spess, L., 2005. Do bilateral investment treaties increase foreign direct investment to developing countries? World Dev. 33, 1567-1585.

Niemann, A., 2013. EU external trade and the Treaty of Lisbon: A revised neo-functionalist approach. J. Contemp. Eur. Res. 9, 634-658.

OECD, 2017. International regulatory co-operation and trade: Understanding the trade costs of regulatory divergence and the remedies. OECD, Paris.

Peterson, L.E., 2011. EU member-states approve negotiating guidelines for India, Singapore and Canada investment protection talks; some European governments fear 'NAFTA-contamination'. Investment Arbitration Reporter. URL https://www.iareporter. com/articles/eu-member-states-approve-negotiating-guidelines-for-india-singaporeand-canada-investment-protection-talks-some-european-governments-fear-naftacontamination/

Pierson, P., 2004. Politics in time: History, institutions, and social analysis. Princeton University Press, Princeton.

Pierson, P., 1994. The path to European integration: A historical institutionalist perspective. Harvard University and Russel Sage Foundation, Cambridge, MA.

Pollack, M.A., 2003. The engines of European integration: Delegation, agency, and agenda setting in the EU. Oxford University Press, Oxford.

Poulsen, L., Bonnitcha, J., Yackee, J.W., 2015. Transatlantic investment treaty protection, CEPS Special Report. CEPS, Brussels. 


\section{Introduction}

Reinisch, A., 2013. The future shape of EU investment agreements. ICSID Rev. - Foreign Invest. Law J. 28, 179-196. doi:10.1093/icsidreview/sit007

Rogowski, R., 1989. Commerce and coalitions: How trade affects domestic political alignments. Princeton University Press, Princeton.

Rosamond, B., 2000. Theories of European integration. Palgrave Macmillan, Basingstoke.

Salacuse, J.W., 2010. The law of investment treaties, 1st ed. Oxford University Press, Oxford.

Schmidt, S., 1998. Commission activism: Subsuming telecommunications and electricity under European competition law. J. Eur. Public Policy 5, 169-184. doi:10.1080/ 13501768880000081

Stacey, J., Rittberger, B., 2003. Dynamics of formal and informal institutional change in the EU. J. Eur. Public Policy 10, 858-883. doi:10.1080/1350176032000148342

Streeck, W., Thelen, K.A. (Eds.), 2005. Beyond continuity: Institutional change in advanced political economies. Oxford University Press, Oxford.

UNCTAD, 2017. Investment policy hub [WWW Document]. URL http://investmentpolicyhub.unctad.org/IIA (accessed 7.15.11).

UNCTAD, 2014a. Recent developments in Investor-State Dispute Settlement (ISDS). IIA Issues Note.

UNCTAD, 2014b. The impact of international investment agreements on foreign direct investment: An overview of empirical studies 1998-2014. IIA Issues Note.

Viner, J., 1950. The customs union issue. Carnegie Endowment for International Peace, New York.

Wiener, A., 2009. European integration theory, 2nd ed. Oxford University Press, Oxford.

Woll, C., 2008. Firm interests: How governments shape business lobbying on global trade, Cornell studies in political economy. Cornell University Press, Ithaca, NY.

Woll, C., Artigas, A., 2007. When trade liberalization turns into regulatory reform: The impact on business-government relations in international trade politics. Regul. Gov. 1, 99-182.

Woolcock, S., 2011. European Union economic diplomacy: The role of the EU in external economic relations, Global finance series. Ashgate, Burlington.

Young, A.R., 2016. Not your parent's trade politic: The transatlantic trade and investment partnership negotiations. Rev. Int. Polit. Econ. 23, 345-378.

Young, A.R., 2001. Extending European cooperation: The European Union and the 'new' international trade agenda, EUI Working Papers. RSC. European University Institute, Economics Department. 


\section{Introduction}

Alschner, W. , 2013. Americanization of the BIT universe: The influence of Friendship, Commerce and Navigation (FCN) treaties on modern investment treaty law. Goettingen J. Int. Law 5, 455-486.

Alvarez, J.E. , 2009. The Public International Law Regime governing international investment, Recueil de cours of the Hague Academy of International Law. Martinus Nijhoff Publishers, Leiden.

Baetens, F. , 2015. Transatlantic investment treaty protection: A response to Poulsen, Bonnitcha and Yackee, CEPS Special Report. CEPS, Brussels.

Basedow, R. , Kauffmann, C. , 2016. International trade and good regulatory practices: Assessing the trade impacts of regulation. OECD Regul. Policy Work. Pap. 4.

Bickerton, C. , Hodson, D. , Puetter, U. , 2015. The new intergovernmentalism: European integration in the post-maastricht era. J. Common Mark. Stud. 53, 703-722.

Billiet, S. , 2006. From GATT to the WTO: The internal struggle for external competences in the EU. J. Common Mark. Stud. 44, 899-919.

Bischoff, J.A. , 2011. Just a little BIT of 'mixity'? The EU's role in the field of international investment protection law. Common Mark. Law Rev. 48, 1527-1570.

Blonigen, B.A. , Piger, J. , 2014. Determinants of foreign direct investment. Can. J. Econ. 47, 775-812. doi:10.1111/caje.12091

Börzel, T. , 2013. Comparative regionalism: European integration and beyond, in: Carl-snaes, W. , Risse, T. , Simmons, B. (Eds.), Handbook of international relations. Sage, London, pp. 501-530.

Busse, M. , Königer, J. , Nunnenkamp, P. , 2010. FDI promotion through bilateral investment treaties: More than a bit? Rev. World Econ. 146, 147-177. doi:10.1007/s10290-009-0046-x

Büthe, T. , 2016. Historical institutionalism and institutional development in the EU: The development of supranational authority over government subsidies (State Aid), in: Rixen, T. , Viola, L.A. , Zürn, M. (Eds.), Historical institutionalism and international relations: Explaining institutional development in world politics. Oxford University Press, Oxford, pp. 37-66.

Colen, L. , Persyn, D. , Guariso, A. , 2014. What type of FDI is attracted by bilateral investment treaties? LICOS Discuss. Pap. 346/2014.

Da Conceição, E. , 2010. Who controls whom? Dynamics of power delegation and agency Iosses in EU trade politics. JCMS J. Common Mark. Stud. 48, 1107-1126.

Da Conceição-Heldt, E. , Meunier, S. , 2014. Speaking with a single voice: Internal cohesiveness and external effectiveness of the EU in global governance. J. Eur. Public Policy 21, 961-979.

Dimopoulos, A. , 2011. EU foreign investment law. Oxford University Press, Oxford.

Dolzer, R. , Schreuer, C. , 2012. Principles of international investment law, 2nd ed. Oxford University Press, Oxford.

Dür, A. , 2008. Bringing economic interests back into the study of EU trade policy-making. Br. J. Polit. Int. Relat. 10, 27-45.

Eckhardt, J. , 2015. Business lobbying and trade governance. Palgrave Macmillan, Basingstoke.

Egger, P. , Merlo, V. , 2007. The impact of bilateral investment treaties on FDI dynamics. World Econ. 30, 1536-1549.

Eilmansberger, T. , 2009. Bilateral investment treaties and EU law. Common Mark. Law Rev. 46, 383-429.

Elsig, M. , 2002. The EU's common commercial policy: Institutions, interests and ideas.

Ashgate, London.

European Commission , 2010a. Proposal for a regulation of the European Parliament and the Council establishing transitional arrangements for bilateral investment agreements between Member States and third countries (COM(2010) 344 final). Brussels.

European Commission , 2010b. Towards a comprehensive European international investment policy (COM(2010)343). Brussels.

European Court of Justice , 2017. Opinion 2/15 (ECLI/EU/C/2017/376). Luxemburg.

Frieden, J. , 1991. Invested interests: The politics of national economic policies in a world of global finance. Int. Organ. 45, 425-451. 
Grossmann, G. , Helpman, E. , 1995. The politics of free trade agreements. Am. Econ. Rev. 85, 667-690.

Hallward-Driemeier, M. , 2003. Do bilateral investment treaties attract foreign direct investment? Only a bit? and they could bite, policy research working papers. The World Bank.

doi:10.1596/1813-9450-3121

Hiscox, M. , 2002. International trade and political conflict: Commerce, coalitions, and mobility. Princeton University Press, Princeton.

Hoffmeister, F. , Ünüvar, G. , 2012. From BITS and Pieces towards European investment agreements. Presented at the EU and Investment Agreements, Vienna.

Kerremans, B. , 2004. What went wrong in Cancún? A principal-agent view of the EU's rationale towards the Doha Development Round. Eur. Foreign Aff. Rev. 9, 363-393.

Kleinheisterkamp, J. , 2014. Financial responsibility in European international investment policy. Int. Comp. Law Q. 63, 449-476. doi:10.1017/S0020589314000116

Krugman, P. , Obstfeld, M. , Melitz, M. , 2014. International trade: Theory and policy: Global edition, 10th ed. Pearson, New York.

Lavranos, N. , 2013. The new EU Investment Treaties: Convergence towards the NAFTA model as the new Plurilateral Model BIT text? Vrije Universiteit Brussel. URL

https://cris.cumulus.vub.ac.be/portal/files/29952551/SSRN_id2241455.pdf

Mahoney, J. , Thelen, K. (Eds.), 2010. Explaining institutional change: Ambiguity, agency, and power, 1st ed. Cambridge University Press, Cambridge.

Manger, M. , 2009. Investing in protection: The politics of preferential trade agreements between north and south. Cambridge University Press, Cambridge.

Mestral, A.L.C.D. , Lévesque, C. , 2013. Improving international investment agreements. Routledge, London.

Meunier, S. , 2017. Integration by stealth: How the European Union gained competence over foreign direct investment. J. Common Mark. Stud. 1-18.

Meunier, S. , 2005. Trading voices: The European Union in international commercial negotiations. Princeton University Press, Princeton.

Mills, A. , 2011. Antinomies of public and private at the foundations of international investment law and arbitration. J. Int. Econ. Law 14, 469-503.

Milner, H. , 1999. The political economy of international trade. Annu. Rev. Polit. Sci. 2, 91-114. Moravcsik, A. , 1998. The choice for Europe: Social purpose and state power from Messina to Maastricht. Cornell Univeristy Press, Ithaca.

Moravcsik, A. , Schimmelfennig, F. , 2009. European Integration Theory. Liberal intergovernmentalism, in: Wiener, A. , Diez, T. (Eds.). Oxford University Press, Oxford, pp. 67-87.

Neumayer, E. , Spess, L. , 2005. Do bilateral investment treaties increase foreign direct investment to developing countries? World Dev. 33, 1567-1585.

Niemann, A. , 2013. EU external trade and the Treaty of Lisbon: A revised neo-functionalist approach. J. Contemp. Eur. Res. 9, 634-658.

OECD , 2017. International regulatory co-operation and trade: Understanding the trade costs of regulatory divergence and the remedies. OECD, Paris.

Peterson, L.E. , 2011. EU member-states approve negotiating guidelines for India, Singapore and Canada investment protection talks; some European governments fear 'NAFTA-

contamination'. Investment Arbitration Reporter. URL https://www.iareporter.com/articles/eumember-states-approve-negotiating-guidelines-for-india-singapore-and-canada-investmentprotection-talks-some-european-governments-fear-nafta-contamination/

Pierson, P. , 2004. Politics in time: History, institutions, and social analysis. Princeton University Press, Princeton.

Pierson, P. , 1994. The path to European integration: A historical institutionalist perspective. Harvard University and Russel Sage Foundation, Cambridge, MA.

Pollack, M.A. , 2003. The engines of European integration: Delegation, agency, and agenda setting in the EU. Oxford University Press, Oxford.

Poulsen, L. , Bonnitcha, J. , Yackee, J.W. , 2015. Transatlantic investment treaty protection, CEPS Special Report. CEPS, Brussels.

Reinisch, A. , 2013. The future shape of EU investment agreements. ICSID Rev. - Foreign Invest. Law J. 28, 179-196. doi:10.1093/icsidreview/sit007 
Rogowski, R. , 1989. Commerce and coalitions: How trade affects domestic political alignments. Princeton University Press, Princeton.

Rosamond, B. , 2000. Theories of European integration. Palgrave Macmillan, Basingstoke.

Salacuse, J.W. , 2010. The law of investment treaties, 1st ed. Oxford University Press, Oxford.

Schmidt, S. , 1998. Commission activism: Subsuming telecommunications and electricity under European competition law. J. Eur. Public Policy 5, 169-184. doi:10.1080/13501768880000081 Stacey, J. , Rittberger, B. , 2003. Dynamics of formal and informal institutional change in the EU. J. Eur. Public Policy 10, 858-883. doi:10.1080/1350176032000148342

Streeck, W. , Thelen, K.A. (Eds.), 2005. Beyond continuity: Institutional change in advanced political economies. Oxford University Press, Oxford.

UNCTAD , 2017. Investment policy hub [WWW Document]. URL http://investmentpolicyhub.unctad.org/IIA (accessed 7.15.11).

UNCTAD , 2014a. Recent developments in Investor-State Dispute Settlement (ISDS). IIA Issues Note.

UNCTAD , 2014b. The impact of international investment agreements on foreign direct investment: An overview of empirical studies 1998-2014. IIA Issues Note.

Viner, J. , 1950. The customs union issue. Carnegie Endowment for International Peace, New York.

Wiener, A. , 2009. European integration theory, 2nd ed. Oxford University Press, Oxford. Woll, C. , 2008. Firm interests: How governments shape business lobbying on global trade, Cornell studies in political economy. Cornell University Press, Ithaca, NY.

Woll, C. , Artigas, A. , 2007. When trade liberalization turns into regulatory reform: The impact on business-government relations in international trade politics. Regul. Gov. 1, 99-182.

Woolcock, S. , 2011. European Union economic diplomacy: The role of the EU in external economic relations, Global finance series. Ashgate, Burlington.

Young, A.R. , 2016. Not your parent's trade politic: The transatlantic trade and investment partnership negotiations. Rev. Int. Polit. Econ. 23, 345-378.

Young, A.R. , 2001. Extending European cooperation: The European Union and the 'new' international trade agenda, EUI Working Papers. RSC. European University Institute,

Economics Department.

\section{European integration theory and the EU's new international investment policy}

Alschner, W. , 2013. Americanization of the BIT universe: The influence of Friendship, Commerce and Navigation (FCN) treaties on modern investment treaty law. Goettingen J. Int. Law 5, 455-486.

Alter, K. , 2009. The European court's political power. Oxford University Press, Oxford. Baccini, L. , Dür, A. , 2012. The new regionalism and policy interdependency. Br. J. Polit. Sci. 42, 57-79.

Baldwin, M. , 2006. EU trade politics: Heaven or hell? J. Eur. Public Policy 13, 926-942.

Baldwin, R. , 2006. Multilateralizing regionalism: Spaghetti bowls as building blocs on the path to global free trade. World Econ. 29, 1451-1518.

Blonigen, B.A. , Piger, J. , 2014. Determinants of foreign direct investment. Can. J. Econ. 47, 775-812. doi:10.1111/caje.12091

Börzel, T. , 2013. Comparative regionalism: European integration and beyond, in: Carl-snaes, W. , Risse, T. , Simmons, B. (Eds.), Handbook of international relations. Sage, London, pp. 501-530.

Busse, M. , Nunnenkamp, P. , Spatareanu, M. , 2010. Foreign direct investment and labor rights: A panel analysis of bilateral FDI flows. Econ. Lett. 11, 270-272.

Caporaso, J. , Keeler, J. , 1995. The European Union and regional integration theory, in: Rhodes, C. , Mazey, S. (Eds.), The state of the European Union. Lynne Rienner Publishers, Boulder, pp. 29-62.

Colen, L. , Persyn, D. , Guariso, A. , 2014. What type of FDI is attracted by bilateral investment treaties?, LICOS Discuss. Pap. 346/2014. 
Copeland, P. , James, S. , 2014. Policy windows, ambiguity and commission entrepreneur-ship: Explaining the relaunch of the European Union's economic reform agenda. J. Eur. Public Policy 21, 1-19. doi:10.1080/13501763.2013.800789

Cotula, L. , Weng, X. , Ma, Q. , Ren, P. , 2016. China-Africa investment treaties: Do they work? IIED, London.

Crouch, C. , 2005. Models of capitalism. New Polit. Econ. 10, 439-456.

Da Conceição, E. , 2010. Who controls whom? Dynamics of power delegation and agency losses in EU trade politics. JCMS J. Common Mark. Stud. 48, 1107-1126.

da Conceição-Heldt, E. , 2011. Negotiating trade liberalization at the WTO. Palgrave Macmillan, London, UK.

da Conceição-Heldt, E. , Meunier, S. , 2014. Speaking with a single voice: Internal cohesiveness and external effectiveness of the EU in global governance. J. Eur. Public Policy 21, 961-979.

Da Conceiçao-Heldt, E.D. , 2009. Delegation of power and agency losses in EU trade politics, EUI Work. Pap.

Dahl, R.A. , 2005. Who governs? Democracy and power in the American city, 2nd Rev ed. Yale University Press, New Haven.

De Bièvre, D. , Dür, A. , 2005. Constituency interests and delegation in European and American trade policy. Comp. Polit. Stud. 38, 1271-1296.

De Bièvre, D. , Jappe, E. , 2010. The political economy of EU anti-dumping reform, ECIPE Work. Pap. 03/2010.

Delreux, T. , Kerremans, B. , 2008. How agents control principals, IIEB Work. Pap. 28.

DiMaggio, P. , Powell, W. , 1991. The new institutionalism and organizational analysis.

Princeton University Press, Princeton.

Dolzer, R. , Schreuer, C. , 2012. Principles of international investment law, 2nd ed. Oxford University Press, Oxford.

Dür, A. , 2012. Key Controversies in European Inegration. Why interest groups dominate the EU's foreign economic policies, in: Zimmerman, H. , Dür, A. (Eds.). Palgrave Macmillan, Basingstoke, pp. 177-183.

Dür, A. , 2008. Bringing economic interests back into the study of EU trade policy-making. Br. J. Polit. Int. Relat. 10, 27-45.

Dür, A. , 2007. EU trade policy as protection for exporters: The agreements with Mexico and Chile. J. Common Mark. Stud. 45, 833-855.

Egger, P. , Merlo, V. , 2007. The impact of bilateral investment treaties on FDI dynamics. World Econ. 30, 1536-1549.

Elsig, M. , 2002. The EU's common commercial policy: Institutions, interests and ideas.

Ashgate, London.

European Commission , 2010. Towards a comprehensive European international investment policy (COM(2010)343). Brussels.

European Commission , 1995. A level playing field for direct investment world-wide (COM(95)42 final). Brussels.

Eurostat , 2017. Foreign direct investments [WWW Document]. URL

http://ec.europa.eu/eurostat/web/structural-business-statistics/global-value-chains/fdi.

Frennhoff Larsén, M. , 2007. Principal-agent analysis with one agent and two principals:

European Union trade negotiations with South Africa. Polit. Policy 35, 440-463.

Frieden, J. , 1991. Invested interests: The politics of national economic policies in a world of global finance. Int. Organ. 45, 425-451.

Garrett, G. , 1995. The politics of legal integration in the European Union. Int. Organ. 49, 171-181. doi:10.1017/S0020818300001612

Garrett, G. , 1992. International cooperation and institutional choice: The European

Community's internal market. Int. Organ. 46, 533-560.

George, A. , Bennett, A. , 2005. Case studies and theory development in the social sciences, BCSIA studies in international security. MIT Press, Cambridge.

Gugler, P. , Tomsik, V. , 2006. The North American and European approach in the international investment agreements, NCCR Work. Pap. 2006/04.

Haas, E.B. , 1958. The uniting of Europe: Political, social and economic forces, 1950-1957.

Stevens, London. 
Hall, P. , Soskice, D. , 2001. Varieties of capitalism the institutional foundations of comparative advantage. Oxford University Press, Oxford.

Hallward-Driemeier, M. , 2003. Do bilateral investment treaties attract foreign direct investment? Only a bit? and they could bite, policy research working papers. The World Bank.

doi:10.1596/1813-9450-3121

Hay, C. , 2008. Constructivist institutionalism, in: Rhodes, R.A.W. , Binder, S. , Rockman, B. (Eds.), Oxford handbook of political institutions. Oxford University Press, Oxford, pp. 56-74. Hiscox, M. , 2002. International trade and political conflict: Commerce, coalitions, and mobility. Princeton University Press, Princeton.

Hoffmann, S. , 1966. Obstinate or obsolete? The fate of the nation-state and the case of Western Europe. Daedalus 95, 862-915.

Hooghe, L. , 2012. Images of Europe: How commission officials conceive their institution's role*: Images of Europe. J. Common Mark. Stud. 50, 87-111. doi:10.1111/j.1468-5965.2011.02210.x Hooghe, L. , 2005. Many roads lead to international norms, but few via international socialization: A case study of the European commission. Int. Organ. 59, 861-898.

Hooghe, L. , 2003. Europe divided? Elites vs public opinion on European integration. Eur. Union Polit. 4, 281-304.

Hooghe, L. , 2001. The European commission and the integration of Europe: Images of governance. Cambridge University Press, Cambridge.

Hooghe, L. , Kassim, H. , 2012. The commission's services, in: Peterson, J. , Shackelton, M. (Eds.), The institutions of the European Union. Oxford University Press, Oxford, pp. 173-198. Johnston, A.I. , 2001. Treating international institutions as social environment. Int. Stud. Q. 45, 487-515.

Kassim, H. , Peterson, J. , Bauer, M.W. , Connolly, S. , Dehousse, R. , Hooghe, L. , Thompson, A. , 2013. The European commission of the twenty-first century. Oxford University Press, Oxford.

Kaunert, C. , 2011. European internal security: Towards supranational governance in the area of freedom, security and justice. Manchester University Press, Manchester.

Kerremans, B. , 2004. What went wrong in Cancún? A principal-agent view of the EU's rationale towards the Doha Development Round. Eur. Foreign Aff. Rev. 9, 363-393.

Krugman, P. , 1990. Increasing returns and economic geography, Working Paper No. 3275. National Bureau of Economic Research.

Krugman, P. , 1980. Scale economies, product differentiation, and the pattern of trade. Am. Econ. Rev. 70, 950-959.

Kuijper, P.J. , 2007. Fifty years of EC/EU external relations: Continuity and the dialogue between judges and Member States as constitutional legislators. Fordham Int. Law J. 31, 1571-1602.

Laffan, B. , 1997. From policy entrepreneur to policy manager: The challenge facing the European commission. J. Eur. Public Policy 4, 422-438. doi:10.1080/13501769780000081 Lavranos, N. , 2013. The new EU Investment Treaties: Convergence towards the NAFTA model as the new Plurilateral Model BIT text? Vrije Universiteit Brussel.

Lindberg, L.N. , 1963. The political dynamics of European economic integration. Stanford University Press, Stanford.

Mahoney, J. , Thelen, K. (Eds.), 2010. Explaining institutional change: Ambiguity, agency, and power, 1st ed. Cambridge University Press, Cambridge.

Manger, M. , 2009. Investing in protection: The politics of preferential trade agreements between north and south. Cambridge University Press, Cambridge.

Meunier, S. , 2005. Trading voices: The European Union in international commercial negotiations. Princeton University Press, Princeton.

Meunier, S. , Nicolaidis, K. , 2006. The European Union as a conflicted trade power. J. Eur. Public Policy 13, 906-925.

Meunier, S. , Nicolaidis, K. , 1999. Who speaks for Europe? The delegation of trade authority in the EU. J. Common Mark. Stud. 37, 477-507.

Milner, H. , Yoffie, D. , 1989. Between free trade and protectionism: Strategic trade policy and a theory of corporate trade demands. Int. Organ. 43, 239-272.

Mitrany, D. , 1943. A working peace system: An argument for the functional development of international organization, post-war problems. Royal Institute of International Affairs, London. 
Moravcsik, A. , 1998. The choice for Europe: Social purpose and state power from Messina to Maastricht. Cornell Univeristy Press, Ithaca.

Moravcsik, A. , 1993. Preferences and power in the European Community: A liberal intergovernmentalist approach. J. Common Mark. Stud. 31, 473-523.

Moravcsik, A. , 1991. Negotiating the single European Act: National interests and conventional statecraft in the European Community. Int. Organ. 45, 19-56.

Moravcsik, A. , Schimmelfennig, F. , 2009. European Integration Theory. Liberal intergovernmentalism, in: Wiener, A. , Diez, T. (Eds.). Oxford University Press, Oxford, pp. 67-87. Neumayer, E. , Spess, L. , 2005. Do bilateral investment treaties increase foreign direct investment to developing countries? World Dev. 33, 1567-1585.

Niemann, A. , 2013. EU external trade and the Treaty of Lisbon: A revised neo-functionalist approach. J. Contemp. Eur. Res. 9, 634-658.

Niemann, A. , 2004. Between communicative action and strategic action: The Article 113 committee and the negotiations on the WTO basic telecommunications services agreement. $\mathrm{J}$.

Eur. Public Policy 11, 379-407.

Pierson, P. , 2004. Politics in time: History, institutions, and social analysis. Princeton University Press, Princeton.

Pierson, P. , Skocpol, T. , 2002. Historical institutionalism in contemporary political science, in: Katznelson, I. , Milner, H. (Eds.), Political science: State of the discipline. W.W. Norton, New York, pp. 693-721.

Pollack, M.A. , 2003. The engines of European integration: Delegation, agency, and agenda setting in the EU. Oxford University Press, Oxford.

Reinisch, A. , 2013. The future shape of EU investment agreements. ICSID Rev. - Foreign Invest. Law J. 28, 179-196. doi:10.1093/icsidreview/sit007

Reiter, J. , 2005. The European Union as actor in international relations: The role of the external environment for EU institutional design, in: Elgström, O. , Jönsson, C. (Eds.), European Union negotiations: Processes, networks and institutions union. Routledge, London, pp. 148-163.

Rogowski, R. , 1989. Commerce and coalitions: How trade affects domestic political alignments. Princeton University Press, Princeton.

Rosamond, B. , 2000. Theories of European integration. Palgrave Macmillan, Basingstoke. Sauvant, K. , Sachs, L. (Eds.), 2009. The effect of treaties on foreign direct investment: Bilateral investment treaties, double taxation treaties and investment flows. Oxford University Press, Oxford.

Schafer, J. , 2014. European commission officials' policy attitudes. JCMS J. Common Mark. Stud. 52, 911-927. doi:10.1111/jcms.12115

Schmidt, S. , 1998a. Commission activism: Subsuming telecommunications and electricity under European competition law. J. Eur. Public Policy 5, 169-184.

doi:10.1080/13501768880000081

Schmidt, S. , 1998b. Liberalisierung in Europa. Campus, Frankfurt.

Schmitter, P. , 2009. Neo-neo-functionalism, in: Wiener, A. , Diez, T. (Eds.), European integration theory. Stevens, London.

Schumpeter, J.A. , 1934. The theory of economic development: An inquiry into profits, capital, credit, interest, and the business cycle. Transaction Publishers.

Shepsle, K. , 2008. Rational choice institutionalism, in: Rhodes, R.A.W. , Binder, S. , Rock-man, B. (Eds.), The Oxford handbook of political institutions. Oxford University Press, Oxford, pp. 23-38.

Stacey, J. , Rittberger, B. , 2003. Dynamics of formal and informal institutional change in the EU. J. Eur. Public Policy 10, 858-883. doi:10.1080/1350176032000148342

Streeck, W. , Thelen, K.A. (Eds.), 2005. Beyond continuity: Institutional change in advanced political economies. Oxford University Press, Oxford.

Tallberg, J. , 2006. Leadership and negotiation in the European Union, themes in European governance. Cambridge University Press, Cambridge.

Tallberg, J. , 2000. The anatomy of autonomy: An institutional account of variation in supranational influence. J. Common Mark. Stud. 38, 843-864.

Thelen, K. , 2004. How institutions evolve: The political economy of skills in Germany, Britain, the United States, and Japan. Cambridge University Press, Cambridge.

UNCTAD , 2017. Investment policy hub [WWW Document]. URL

http://investmentpolicyhub.unctad.org/IIA (accessed 7.15.11). 
UNCTAD , 2014a. Recent developments in Investor-State Dispute Settlement (ISDS). IIA Issues Note.

UNCTAD , 2014b. The impact of international investment agreements on foreign direct investment: An overview of empirical studies 1998-2014. IIA Issues Note.

Waltz, K. , 1979. Theory of international politics. McGraw-Hill, Boston.

Weaver, R.K. , 1986. The politics of blame avoidance. J. Public Policy 6, 371-398.

Wildavsky, A. , 1987. Choosing preferences by constructing institutions: A cultural theory of preference formation. Am. Polit. Sci. Rev. 81, 4-21. doi:10.2307/1960776

Woll, C. , 2008. Firm interests: How governments shape business lobbying on global trade, Cornell studies in political economy. Cornell University Press, Ithaca, NY.

Woll, C. , 2006. The road to external representation: The European commission's activism in international air transport. J. Eur. Public Policy 13, 52-69. doi:10.1080/13501760500380734 Woolcock, S. , 2011. European Union economic diplomacy: The role of the EU in external economic relations, Global finance series. Ashgate, Burlington.

Woolcock, S. , Bayne, N. (Eds.), 2007. The new economic diplomacy, 2nd ed. Ashgate, London.

Yackee, J.W. , 2010. How much do U.S. corporations know (and care) about bilateral investment treaties? Some hints from new survey evidence. Columbia FDI Perspect. Yackee, J.W. , 2009. Do BITs really work? Revisiting the empirical link between investment treaties and foreign direct investment, in: Sauvant, K. , Sachs, L. (Eds.), The effect of treaties on foreign direct investment: Bilateral investment treaties, double taxation treaties and investment flows. Oxford University Press, Oxford.

Young, A.R. , 2016. Not your parent's trade politic: The transatlantic trade and investment partnership negotiations. Rev. Int. Polit. Econ. 23, 345-378.

Young, A.R. , 2002. Extending European cooperation: The European Union and the 'new' international trade agenda. Manchester University Press, Manchester.

Young, A.R. , 2001. Extending European cooperation: The European Union and the 'new' international trade agenda, EUI working papers. RSC. European University Institute, Economics Department.

\section{An introduction to international investment and its regime}

Alschner, W. , 2013. Americanization of the BIT universe: The influence of Friendship, Commerce and Navigation (FCN) treaties on modern investment treaty law. Goettingen J. Int. Law 5, 455-486.

Alvarez, J.E. , 2009. The Public International Law Regime governing international investment, Recueil de cours of the Hague Academy of International Law. Martinus Nijhoff Publishers, Leiden.

The Avalon Project (Yale Law School Lillian Goldman Law Library) , 1999. Treaty of amity and commerce between the United States and France, February 61778 [WWW Document]. URL http://avalon.law.yale.edu/18th_century/fr1788-1.asp (accessed 11.24.11).

Blonigen, B.A. , Piger, J. , 2014. Determinants of foreign direct investment. Can. J. Econ. 47, 775-812. doi:10.1111/caje.12091

Busse, M. , Nunnenkamp, P. , Spatareanu, M. , 2010. Foreign direct investment and labor rights: A panel analysis of bilateral FDI flows. Econ. Lett. 11, 270-272.

Cain, P.J. , 1978. J. A. Hobson, Cobdenism, and the radical theory of economic imperialism, 1898-1914. Econ. Hist. Rev., new series 31, 565-584.

Colen, L. , Persyn, D. , Guariso, A. , 2014. What type of FDI is attracted by bilateral investment treaties?, LICOS Discuss. Pap. 346/2014.

Dattu, R. , 2000. A journey from Havana to Paris: The fifty-year quest for the elusive multilateral agreement on investment. Fordham Int. Law J. 24, 275-316.

Dimopoulos, A. , 2011. EU foreign investment law. Oxford University Press, Oxford.

Dolzer, R. , Schreuer, C. , 2012. Principles of international investment law, 2nd ed. Oxford University Press, Oxford. 
Dolzer, R. , Schreuer, C. , 2008. Principles of international investment law. Oxford University Press, Oxford.

Dolzer, R. , Stevens, M. , 1995. Bilateral investment treaties. M. Nijhoff, The Hague.

Dunning, J. , 2008. Multinational enterprises and the global economy, 2nd ed. Edward Elgar, Cheltenham.

Dunning, J. , 1981. International production and the multinational enterprise. Allen \& Unwin, Crows Nest.

Elkmans, Z ., Guzman, A. , Simmons, B. , 2006. Competing for capital: The diffusion of bilateral investment treaties, 1960-2000. Int. Organ. 60, 811-846.

Euler, D. , Gehring, M. , Scherer, M. (Eds.), 2015. Transparency in international investment arbitration. Cambridge University Press, Cambridge.

European Communities , 1988. Nomenclature of the capital movements referred to in article 1 of the directive. Off. J. Eur. Communities L-178, 8-12.

European Court of Justice , 2017. Opinion 2/15 (ECLI/EU/C/2017/376). Luxemburg.

Fontanelli, F. , Bianco, G. , 2013. The inevitable convergence of the US and the EU on the protection of foreign investments: BITs, PTAs, and incomplete contracts, in: European Society of International Law Conference Paper Series. Presented at the Amsterdam Research Forum, Amsterdam.

Gordon, K. , 2008. Investment guarantees and political risk insurance: Institutions, incentives and development: OECD invest. Policy Perspect.

Guzman, A. , 1997. Why LDCs sign treaties that hurt them: Explaining the popularity of bilateral investment treaties. Va. J. Int. Law 38, 639-688.

Hallward-Driemeier, M. , 2003. Do bilateral investment treaties attract foreign direct investment? Only a bit? and they could bite, policy research working papers. The World Bank. doi:10.1596/1813-9450-3121

IMF , 2009. Balance of payments and international investment position manual, 6th ed. Washington, DC.

Johannsen, E.L. , 2009. Die Kompetenz der Europäischen Union für ausländische Direktinvestitionen nach dem Vertrag von Lissabon. Beiträge zum Transnationalem Wirtschaftsrecht.

Jones, G. , 2005. Multinationals and global capitalism. Oxford University Press, Oxford. Krajewski, M. , 2005. External trade law and the constitutional treaty: Towards a federal and more democratic common commercial policy? Common Mark. Law Rev. 42, 91-127.

Krasner, S. , 1982. Structural causes and regime consequences: Regimes as intervening variables. Int. Organ. 36, 185-205.

Lavranos, N. , 2013. The new EU investment treaties: Convergence towards the NAFTA model as the new Plurilateral Model BIT text? Vrije Universiteit Brussel.

Lipsey, R.E. , 2002. Home and host country effects of FDI. Presented at the ISIT Conference on Challenges to Globalization, Lidingö, Sweden.

MIGA , 2011. Types of coverage [WWW Document]. URL www.miga.org/investmentguarantees/index.cfm?stid=1797\#toc5.

Mills, A. , 2011. Antinomies of public and private at the foundations of international investment law and arbitration. J. Int. Econ. Law 14, 469-503.

Navaretti, G.B. , Venables, A. , 2004. Multinational firms in the world economy. Princeton University Press, Princeton.

Neumayer, E. , Spess, L. , 2005. Do bilateral investment treaties increase foreign direct investment to developing countries? World Dev. 33, 1567-1585.

OECD , 2008. OECD benchmark definition of foreign direct investment. Paris. OECD Publishing.

Rajoo, S. , 2016. Annulment of investment arbitration awards. Int. Invest. Treaty Arbitr. Rev. 1, 159-215.

Reinisch, A. , 2016. The European Union and investor-state dispute settlement: From investorstate arbitration to a permanent investment court. CIGI Invest.-State Arbitr. Ser. 2.

Reinisch, A. , 2013. The future shape of EU investment agreements. ICSID Rev. - Foreign Invest. Law J. 28, 179-196. doi:10.1093/icsidreview/sit007

Ruggie, J.G. , 1982. International regimes, transactions, and change: Embedded liberalism in the postwar economic order. Int. Organ. 36, 379-415. doi:10.1017/S0020818300018993 
Sauvant, K. , Sachs, L. (Eds.), 2009. The effect of treaties on foreign direct investment: Bilateral investment treaties, double taxation treaties and investment flows. Oxford University Press, Oxford.

Schill, S. , 2009. The multilatrelaisation of international investment law. Cambridge University Press, Cambridge.

Sornarajah, M. , 2013. The international law on foreign investment, 3rd ed. Cambridge University Press, Cambridge.

Stein, E. , Daude, C. , 2007. Longitude matters: Time zones and the location of foreign direct investment. J. Int. Econ. 71, 96-112.

UNCTAD , 2017a. Investment policy hub [WWW Document]. URL

http://investmentpolicyhub.unctad.org/IIA (accessed 7.15.11).

UNCTAD , 2017b. World Investment Report 2017: Investment and the digital economy.

UNCTAD, Geneva.

UNCTAD , 2016. World Investment Report 2016. UNCTAD, Geneva.

UNCTAD , 2015. Investor-State Dispute Settlement review of developments in 2014. IIA Issues

Note 2.

UNCTAD , 2014a. The impact of international investment agreements on foreign direct investment: An overview of empirical studies 1998-2014. IIA Issues Note.

UNCTAD, 2014b. UNCTADSTAT [WWW Document]. URL

http://unctadstat.unctad.org/ReportFolders/reportFolders.aspx (accessed 3.1.14).

UNCTAD , 2014c. World Investment Report 2014. UNCTAD, Geneva.

UNCTAD , 2013. Recent developments in Investor-State Dispute Settlement (ISDS). IIA Issues Note 1.

UNCTAD , 2012. Fair and equitable treatment. UNCTAD Ser. Issues Int. Invest. Agreem. II.

UNCTAD , 2011. World Investment Report 2012. UNCTAD, Geneva.

UNCTAD , 2006. The entry into Force of Bilateral Investment Treaties (BITs). IIA Monit. 3.

UNCTAD , 2005. Latest developments in investor-state dispute settlement. IIA Monit. 3.

UNCTAD , 1999. Trends in international investment agreements: An overview

(UNCTAD/ITE/IIT/13).

Vandevelde, K., 1997. Sustainable liberalism and the international investment regime. Mich. J. Int. Law 19, 373-399.

Velde, D.W. te , 2006. Foreign direct investment and development: An historical perspective. Overseas Development Institute, London.

Weiss, M. , 2007. The U.S. Bilateral Investment Treaty Program: An overview. CRS Rep. Congr. RL33978.

Woolcock, S. , Bayne, N. (Eds.), 2007. The new economic diplomacy, 2nd ed. Ashgate, London.

WTO , 2002. WG/WGTI/W/115 Communication from the European Community and its Member States.

Yackee, J.W. , 2010. How much do U.S. corporations know (and care) about bilateral investment treaties? Some hints from new survey evidence. Columbia FDI Perspect.

\section{An overview of EU international investment policymaking under the Treaty of Lisbon}

Benyon, F. , 2010. Direct investment, national champions and EU treaty freedoms: From Maastricht to Lisbon, Modern studies in European law; 24. Hart, Oxford.

Bernhagen, P. , Dür, A. , Marschall, D. , 2015. Information or context: What accounts for positional proximity between the European Commission and lobbyists? J. Eur. Public Policy 22, 570-587.

Bischoff, J.A. , 2011. Just a little BIT of 'mixity'? The EU's role in the field of international investment protection law. Common Mark. Law Rev. 48, 1527-1570.

Bourgeois, J. , 2003. Title IX: Gemeinsame Handelspolitik, in: Groeben, H. von der , Schwarze, J. (Eds.), Kommentar Zum Vertrag Über Die Europäische Union Und Zur Gründung Der Europäischen Gemeinschaft. Nomos, Baden-Baden, pp. 638-762. 
Bungenberg, M. , Griebel, J. , Hindelang, S. (Eds.), 2011. International investment law and EU law. Springer, Heidelberg.

Bungenberg, M. , Herrmann, C. (Eds.), 2013. Common commercial policy after Lisbon.

Heidelberg,Springer.

Consilium , 2017. Trade policy committee. Brussels.

Cremona, M. , 2015. Negotiating the Transatlantic Trade and Investment Partnership (TTIP).

Common Mark. Law Rev. 52, 351-362.

De Bièvre, D. , Dür, A. , 2005. Constituency interests and delegation in European and American trade policy. Comp. Polit. Stud. 38, 1271-1296.

Deyvust, Y. , 2013. European Union law and practice in the negotiation and conclusion of international trade agreements. J. Int. Bus. Law 12, 259-316.

Dimopoulos, A. , 2014. The involvement of the EU in investor-state dispute settlement: A question of responsibilities. Common Mark. Law Rev. 51, 1671-1720.

Dimopoulos, A. , 2011. EU foreign investment law. Oxford University Press, Oxford.

Dolzer, R. , Schreuer, C. , 2008. Principles of international investment law. Oxford University Press, Oxford.

Dür, A. , 2012. Key Controversies in European Integration. Why interest groups dominate the EU's foreign economic policies, in: Zimmerman, H. , Dür, A. (Eds.). Palgrave Macmillan, Basingstoke, pp. 177-183.

Dür, A. , 2008. Bringing economic interests back into the study of EU trade policy-making. Br. J. Polit. Int. Relat. 10, 27-45.

Dür, A. , 2007. EU trade policy as protection for exporters: The agreements with Mexico and Chile. J. Common Mark. Stud. 45, 833-855.

Dür, A. , De Bièvre, D. , 2007. Inclusion without influence? NGOs in European trade policy. J. Public Policy 27, 79-101.

Eeckhout, P. , 2011. EU external relations law, 2nd ed., Oxford EU law library. Oxford University Press, Oxford.

Eilmansberger, T. , 2009. Bilateral investment treaties and EU law. Common Mark. Law Rev. 46, 383-429.

Elsig, M. , 2002. The EU's common commercial policy: Institutions, interests and ideas.

Ashgate, London.

European Commission , 2015. Better regulation guidelines. Burssels.

European Commission , 2013. Impact assessment report on the EU-China investment relations (SWD(2013) 185 final). Brussels.

European Court of Justice , 2017. Opinion 2/15 (ECLI/EU/C/2017/376). Luxemburg.

European Union , 2011. Guide to the ordinary legislative procedure. Brussels.

Frieden, J. , 1991. Invested interests: The politics of national economic policies in a world of global finance. Int. Organ. 45, 425-451.

Gordon, K. , 2008. Investment guarantees and political risk insurance: Institutions, incentives and development: OECD invest. Policy Perspect.

Gstöhl, S. , 2013. The European Union's trade policy. Ritsumeikan Int. Aff. 11, 1-22.

Hiscox, M. , 2002. International trade and political conflict: Commerce, coalitions, and mobility.

Princeton University Press, Princeton.

Hooghe, L. , Kassim, H. , 2012. The commission's services, in: Peterson, J. , Shackelton, M. (Eds.), The institutions of the European Union. Oxford University Press, Oxford, pp. 173-198. Kleine, M. , 2013. Informal governance in the European Union: How governments make international organizations work. Cornell University Press, Ithaca, NY.

Klüver, H. , Braun, C. , Beyers, J. , 2015. Legislative lobbying in context: The policy and polity determinants of interest group politics in the European Union. J. Eur. Public Policy 22, 447-461. Krajewski, M. , 2005. External trade law and the constitutional treaty: Towards a federal and more democratic common commercial policy? Common Mark. Law Rev. 42, 91-127.

Meunier, S. , Nicolaidis, K. , 1999. Who speaks for Europe? The delegation of trade authority in the EU. J. Common Mark. Stud. 37, 477-507.

Niemann, A. , 2013. EU external trade and the Treaty of Lisbon: A revised neo-functionalist approach. J. Contemp. Eur. Res. 9, 634-658.

Quick, R. , 2007. Business in economic diplomacy, in: Woolcock, S. , Bayne, N. (Eds.), The new economic diplomacy. Ashgate, Aldershot, pp. 105-121. 
Rogowski, R. , 1989. Commerce and coalitions: How trade affects domestic political alignments. Princeton University Press, Princeton.

Scharpf, F. , 1988. The joint decision trap: Lessons from German federalism and European integration. Public Adm. 66, 239-278.

Seidl-Hohenveldern, I. , 1977. Verischerung nichtkommerzieller Risiken und die Europäische Gemeinschaft, Kölner Studien zur Rechtsvereinheitlichung, Band 1. Carl Heymanns Verlag KG, Köln.

Van den Putte, L. , De VIlle, F. , Orbie, J. , 2015. The European Parliament as an international actor in trade, in: Stavrids, S. , Irrera, D. (Eds.), The European Parliament and its international relations. Routledge, London.

Vedder, C. , 2008. Title IX: Gemeinsame Handelspolitk, in: Grabitz, E. , Hilf, M. , Nettesheim, M. (Eds.), Das Recht Der Europäischen Union. C.H. Beck, München.

Voltolini, B. , 2016. Non-state actors and framing processes in EU foreign policy: The case of EU-Israel relations. J. Eur. Public Policy 23, 1502-1519.

Woll, C. , 2008. Firm interests: How governments shape business lobbying on global trade, Cornell studies in political economy. Cornell University Press, Ithaca, NY.

Woll, C. , Artigas, A. , 2007. When trade liberalization turns into regulatory reform: The impact on business-government relations in international trade politics. Regul. Gov. 1, 99-182.

Woolcock, S. , 2011. European Union economic diplomacy: The role of the EU in external economic relations, Global finance series. Ashgate, Burlington.

Woolcock, S. , 2010. The Treaty of Lisbon and the European Union as an actor in international trade, ECIPE Work. Pap. 1/2010.

Young, A. , 2011. The rise (and fall?) of the EU's performance in the multilateral trading system. J. Eur. Integr. 33, 715-739.

Young, A. , Peterson, J. , 2014. Parochial global Europe: 21st century trade policy. Oxford University Press, Oxford.

Young, A. , Peterson, J. , 2006. The EU and the new trade politics. J. Eur. Public Policy, Young 13, 795-814.

\section{The EU in investment-related negotiations during the Uruguay Round}

Agence Europe , 1992. Statement on U.S. policy on foreign investment (19 February 1992).

Agence Europe , 1991. European and US industrialists call for conclusion to Uruguay round (20 June 1991).

Agence Europe , 1983. Vice-President of the European Commission, Mr Tugendhat, has announced the commission's intention of proposing a stand-still on new restrictions on services business to be followed by a gradual unfreezing of the international services trade (4 November 1983).

Auerbach, S. , 1985. U.S. - Israel sign trade agreement (23 April 1985). Wash. Post.

Buchan, D. , 1992. World Trade News: French ready to fight Gatt concessions (9 October 1992). Financ. Times 4.

Buchan, D. , 1989. World Trade News: Andriessen takes liberal line on investment in EC (21 July 1989). Financ. Times 3.

Cheeseright, P. , 1985a. World Trade News: EEC badly placed for trade-in-services talks (21 November 1985). Financ. Times.

Cheeseright, P. , 1985b. Plea for free trade in Europe (9 January 1985). Financ. Times 2.

Cheeseright, P. , 1983. World Trade News: Gatt consensus may soon emerge on code for trade in services (24 October 1983). Financ. Times 4.

Croome, J. , 1995. Reshaping the world trading system: A history of the Uruguay round. World Trade Organization, Geneva.

Dolzer, R. , Schreuer, C. , 2012. Principles of international investment law, 2nd ed. Oxford University Press, Oxford.

Dullforce, W. , 1990. World Trade News: Splits remain on end to investment flow curbs (6 November 1990). Financ. Times 8. 
Dullforce, W. , 1987. World Trade News: EEC service industries call for freer markets (14 April 1987). Financ. Times 7.

Dullforce, W. , 1986. World Trade News: EEC shifts stance to back trade in services pact (28 May 1986). Financ. Times 12.

European Commission , 1982. GATT ministerial meeting, information note submitted by the commission to the Council of Ministers COM(82)678. Brussels.

Farnsworth, C. , 1982. Trade conferees reach consensus despite disputes (29 November 1982). N. Y. Times.

Financial Times , 1982. The UK government is seeking a standstill agreement in order to stop the introduction of further barriers to trade in services (24 September 1982). Financ. Times.

GATT , 1990. MTN.GNS/W/95.

GATT , 1989a. MTN.GNG/NG12/W/22.

GATT , 1989b. MTN.GNG/NG12/W/14.

GATT , 1989c. MTN.GNG/NG12/W/15.

GATT , 1989d. MTN.GNS/W/50.

GATT , 1989e. MTN.GNS/W/75.

GATT , 1989f. MTN.GNS/W/76.

GATT , 1989g. MTN.GNS/W/77.

GATT , 1988. MTN.GNG/NG12/W/10.

GATT , 1987a. MTN.GNG/NG12/W/2.

GATT , 1987b. MTN.GNG/NG12/W/4.

GATT , 1987c. MTN.GNG/NG12/2.

GATT , 1987d. MTN.GNG/NG12/7.

GATT , 1987e. MTN.GNG/NG12/W/8.

GATT , 1981. GATT/1303.

Glick, L.A. , 1984. Multilateral trade negotiations: World trade after the Tokyo round. Rowman and Allanheld, Totowa.

Guisinger, S. , 1987. Investment related to trade, in: Finger, J.M. , Olechowski, A. (Eds.), The Uruguay round: A handbook for the multilateral trade negotiations. IBRD, Washington, DC, pp. 217-225.

Hindley, B. , 1990. Principles in factor-related trade in services, in: Messerlin, P. , Sauvant, K. (Eds.), The Uruguay round. World Bank, Washington, DC, pp. 12-18.

Messerlin, P. , 1990. The European Community, in: Messerlin, P. , Sauvant, K. (Eds.), The Uruguay round. World Bank, Washington, DC, pp. 132-149.

Montagnon, P. , 1989. World Trade News: Keeping gatt talks on the front burner: Why the Uruguay round is seen as crucial for EC chemicals (14 March 1989). Financ. Times 8.

Montagnon, P. , 1988. World Trade News: Nissan row touches a raw nerve: A dispute over local content requirements (30 September 1988). Financ. Times 8.

Montagnon, P. , Dullforce, W. , 1988. Montreal trade talks: Signs of progress on yardsticks for liberalising services (1 December 1988). Financ. Times 4.

Nikièma, S. , 2014. Performance requirements in investment treaties. IISD Best Pract. Ser.

Paemen, H. , Bensch, A. , 1995. From the GATT to the WTO: The European Community in the Uruguay round, studies in social and economic history. Leuven University Press, Leuven,

Belgium.

Peel, Q. , 1986. World Trade News: EEC bid to defend farm policy/call for all subsidy policies to be included in Gatt talks (18 June 1986). Financ. Times 6.

Reagan, R. , 1986. Presidential radio address [WWW Document]. URL

http://en.wikisource.org/wiki/Presidential_Radio_Address_-_13_September_1986 (accessed 3.9.14).

Salacuse, J.W. , 2010. The law of investment treaties, 1st ed. Oxford University Press, Oxford.

Schott, J.J. , 1994. The Uruguay round: An assessment. Institute for International Economics,

Washington, DC.

Sidhu, K. , 2004. Die Regelung von Direktinvestitionen in der WTO: Das TRIMs-Abkommen und das GATS. V\&R Unipress GmbH, Osnabrück.

Stewart, T. , 1993. The GATT Uruguay round: A negotiating history. Kluwer Law and Taxation Publishers, Deventer; Boston. 
Thomson, R. , 1990. World Trade News (GATT): Quietly, Japan moves to lift rice import ban: Politicians work behind scenes on area of once-loud disagreement (20 November 1990). Financ. Times.

Tyler, C. , 1985. World Trade News: Washington 'will go ahead with trade talks in 1986'/US proposes alternative to Gatt (20 June 1985). Financ. Times 6.

Tyler, C. , 1983. World Trade News: New move to boost trade in services (18 April 1983). Financ. Times 3.

Wayne, S. , 1984. The new U.S. bilateral investment treaties. Berkeley J. Int. Law 2, 192-224. Woolcock, S. , 1990. The Uruguay round: Issues for the European Community and the United States, RIIA discussion paper. Royal Institute of International Affairs, London.

\section{The EU in investment-related negotiations on the Energy Charter Treaty}

Agence Europe , 1998. Energy Charter: Adoption of Supplementary Charter postponed to endJune (5 May 1998).

Agence Europe , 1997a. Energy Charter (22 January 1997).

Agence Europe , 1997b. EU/Energy Charter: First Charter implementing treaty will enter into force in March 1998 (4 December 1997).

Agence Europe , 1994a. Energy plenary session: Will Russia confirm its hopes for early endorsement? (26 February 1994).

Agence Europe , 1994b. General Affairs Council supports energy charter compromise (19 May 1994).

Agence Europe , 1994c. Energy Charter: First implementation treaty to be signed without knowing if the US can accept it (20 September 1994).

Agence Europe , 1994d. United States calls for negotiations to be reopened on energy charter treaty (14 October 1994).

Agence Europe , 1993a. Chairman of the conference on European Energy Charter hopes that an agreement can be reached by summer (31 March 1993).

Agence Europe , 1993b. European conference makes 'considerable progress' towards signature of energy charter (21 December 1993).

Agence Europe , 1993c. Energy Charter could become legal treaty by early 1994 (12 October 1993).

Agence Europe , 1993d. Energy Charter: Results of trilateral meeting between the EC, Russia and the US (15 September 1993).

Agence Europe, 1993e. Significant political questions and technical problems complicate negotiations on European Energy Charter (24 March 1993).

Agence Europe , 1993f. Russian reticence puts European Energy Charter negotiations in deadlock (1 July 1993).

Agence Europe, 1993g. Progress on Energy Charter (6 July 1993).

Agence Europe , 1993h. Energy: Controversial points on Energy Charter to be discussed at the trilateral meeting (4 September 1993).

Agence Europe , 1993i. Commission wants to provoke debate on member countries' approach to energy charter (5 November 1993).

Agence Europe , 1993j. Results of General Affairs Council (10 November 1993).

Agence Europe , 1993k. Council approves two-phase approach in implementing energy charter (11 November 1993).

Agence Europe , 1992a. Work reopened on implementation of European Energy Charter (7 March 1992).

Agence Europe , 1992b. Preparation of the draft basic agreement giving effect to the European Energy Charter (3 April 1992).

Agence Europe, 1992c. Negotiations on the basic agreement of the European Energy Charter are making headway (11 April 1992).

Agence Europe , 1992d. European energy charter implementation to be speeded up from May (15 May 1992). 
Agence Europe , 1992e. Major European energy distributors and trade unions in the sector condemn the commission's energy policy (31 January 1992).

Agence Europe , 1992f. Belgian industry support for proposals on liberalisation of energy markets (3 March 1992).

Agence Europe , 1991a. Community to draw up draft energy charter, organise international conference (17 April 1991).

Agence Europe, 1991b. Energy Council agrees on gas transit directive but not on policy in case of oil supply problems (1 June 1991).

Agence Europe , 1991c. US, Japan and Canada invited to conference on European Energy Charter (19 June 1991).

Agence Europe , 1991d. Participants in energy charter conference stress the need for urgent action (18 July 1991).

Agence Europe , 1991e. Events in USSR lead MEPs to call for an acceleration towards political union (12 September 1991).

Agence Europe , 1991f. The main points of the European Energy Charter have been defined (2 October 1991).

Agence Europe , 1991g. Work resumes on the 'European Energy Charter' (21 September 1991).

Agence Europe , 1991h. Speech by Mr. Lubbers prior to signing of the Energy Charter (17 December 1991).

Agence Europe , 1990a. CSCE Summit; Delors proposal for European Energy Charter Treaty (20 November 1990).

Agence Europe , 1990b. Special edition: European Council Presidency conclusions (16 December 1990).

Agence Europe , 1990c. Rome Summit expected to adopt decisions on cooperation agreement with USSR (24 November 1990).

Bernasconi-Osterwalder, N. , Hoffmann, R.T. , 2012. The German Nuclear Phase-out put to the test in international investment arbitration? Background to the new dispute Vatenfall v. Germany (II), Briefing Note. IISD.

Brzezinski, Z. , Sullivan, P. (Eds.), 1997. Russia and the commonwealth of independent states: Documents, data, and analysis. Center for Strategic and International Studies, Washington, DC. Buchan, D. , 1991. European energy charter finalised (14 February 1991) 4.

Buchan, D. , 1990. EC seeks Soviet energy charter (19 October 1990). Financ. Times 2.

Doré, J. , 1996. Negotiating the Energy Charter Treaty, in: Wälde, T. (Ed.), The Energy Charter Treaty: An East-West gateway for investment and trade. Kluwer Law International, London, pp. 137-155.

Eikeland, P.O. , 2004. The long and winding road to the internal energy market: Consistencies and inconsistencies in EU policy. FNI Rep. 8.

Energy Charter Secretariat , 2004. The Energy Charter Treaty and related documents.

Brussels.

Energy Charter Secretariat, 2003. The Energy Charter Treaty: A reader's guide. Brussels.

European Commission , 1993. The European Energy Charter: Fresh impetus from the European Community (COM(93)542). Brussels.

European Commission , 1991. European Energy Charter (COM(91)36). Brussels.

European Commission, 1985. Completing the Internal Market (COM(85) 310). Brussels.

Evtuhov, C. , Goldfrank, D. , Hughes, L. , Stites, R. , 2004. A history of Russia: Peoples legends, events, forces. Houghton Mifflin Company, New York.

Hill, A. , 1992. CIS hopes for energy charter (20 June 1992). Financ. Times.

Hill, A. , 1991a. Commission sets sights on electricity and gas monopolies (21 October 1991).

Financ. Times.

Hill, A. , 1991b. Soviets to sign energy charter (22 November 1991). Financ. Times 2.

Hill, A. , 1991c. Lubbers in hurry over energy plan (17 December 1991). Financ. Times 2.

Hill, A. , Gardner, D. , 1991. Coup against Gorbachev: EC could halt up to Ecu 1.15bn of aid (20 August 1991). Financ. Times 4.

Hill, A. , Hargreaves, D. , 1991. Mosocow's stance key to European energy charter (15 July 1991). Financ. Times. 
Hill, A. , Lloyd, J. , 1991. The European market: Dutch fear their star guest could spoil Europe's energy party: The Soviet situation has changed so radically the whole charter project risks being bogged down (4 November 1991). Financ. Times 4.

Hosking, G. , 2012. Russian history: A very short introduction. Oxford University Press, Oxford. ITA Law , 2014. Yukos Universal Limited (Isle of Man) v. The Russian Federation, UNCITRAL, PCA Case No. 227 [WWW Document]. URL www.italaw.com/cases/1175 (accessed 10.2.14). Jenkins, D. , 1996. An oil and gas industry perspective, in: Wälde, T. (Ed.), The Energy Charter Treaty: An East-West gateway for investment and trade. Kluwer Law International, London, pp. 187-193.

Johnstone, C. , 1998. Power battle over UK-France trade (10 December 1998). Eur. Voice.

Konoplyanik, A. , 1996. The Energy Charter Treaty: A Russian perspective, in: Wälde, T. (Ed.), The Energy Charter Treaty: An East-West gateway for investment and trade. Kluwer Law International, London, pp. 156-178.

Laurance, B. , 1991. Gas exports still vital to many European economies (21 August 1991). The Guardian.

Lovell, S. , 2009. The Soviet Union. Oxford University Press, Oxford.

Mahoney, J. , Thelen, K. (Eds.), 2010. Explaining institutional change: Ambiguity, agency, and power, 1st ed. Cambridge University Press, Cambridge.

Moravcsik, A. , 1991. Negotiating the single European Act: National interests and conventional statecraft in the European Community. Int. Organ. 45, 19-56.

Müller, W. , 1991. Managing the enlarged European market: A view from VEBA as a

multiproduct energy company, in: Hoffmann, L. , Siefen, H. (Eds.), Energy in Europe: The EastWest dimension. Verlag TÜF Rheinland, Frankfurt, pp. 118-125.

Padget, S. , 1992. The single European energy market: The politics of realization. J. Common Mark. Stud. 30, 53-76.

Palmer, J. , 1991. Reform assurance restores aid from EC (20 February 1991). The Guardian. Pollack, M.A. , 2003. The engines of European integration: Delegation, agency, and agenda setting in the EU. Oxford University Press, Oxford.

Riley, D. , 1991. Risks and opportunities for oil and gas companies, in: Hoffmann, L. , Siefen, H. (Eds.), Energy in Europe: The East-West dimension. Verlag TÜF Rheinland, Frankfurt, pp. 109-117.

Streeck, W. , Thelen, K.A. (Eds.), 2005. Beyond continuity: Institutional change in advanced political economies. Oxford University Press, Oxford.

Thompson, J. , 1998. Russia \& the Soviet Union: An historical introduction form the Kievan State to the present. Westview Press, Oxford.

Wälde, T. , 1996. International investment under the 1994 Energy Charter Treaty, in: Wälde, T. (Ed.), The Energy Charter Treaty: An East-West gateway for investment and trade. Kluwer Law International, London, pp. 251-320.

Young, A.R. , 2002. Extending European cooperation: The European Union and the 'new' international trade agenda. Manchester University Press, Manchester.

Young, A.R. , 2001. Extending European cooperation: The European Union and the 'new' international trade agenda, EUI working papers. RSC. European University Institute, Economics Department.

\section{The EU in negotiations on the multilateral agreement on investment and the Singapore Issues}

Agence Europe , 1998a. EU/OECD/INVESTMENT: UNICE concerned about delays in negotiation of the multilateral agreement on investment (28 March 1998).

Agence Europe , 1998b. EU/United States (17 October 1998).

Agence Europe, 1997a. UE/OCDE/Investissement (28 March 1997).

Agence Europe , 1997b. UE/OCDE: Investissements directs (20 March 1997).

Agence Europe , 1995. Ecofin Council discusses anti-fraud and compensation for investors (23 May 1995). 
British Parliament , 2004. Memorandum by International Financial Services, London [WWW Document]. URL

www.publications.parliament.uk/pa/ld200304/ldselect/ldeucom/104/4020302.htm (accessed 8.10.14).

Brittan, L. , 1998. The Rt Hon Sir Leon Brittan QC Vice-President of the European Commission Declaration: MAI European Parliament Plenary Session Strasbourg, 20 October 1998 (SPEECH/98/212). Strassburg.

Chatignoux, C. , 1998. A quelques jours de la reprise des negociations sur l'Accord multilateral sur l'investissement (AMI), le Premier ministre, Lionel Jospin, a fait savoir hier que la France n'y participerait pas. Echos 6.

Corporate Europe Observatory , 1998. MAIGALOMANIA! Citizens and the environment sacrificed to corporate investment agenda: A briefing by Corporate Europe Observatory [WWW Document]. URL http://archive.corporateeurope.org/mai/index.html (accessed 5.3.13).

Council of Ministers , 1995. 7118/95 Limite GATT 97 Ecofin 68.

De Jonquières, G. , 2003a. Crushed at Cancun (15 September 2003).

De Jonquières, G. , 2003b. Call for UK to stop supporting line on 'Singapore issues' (14 July 2003). Financ. Times.

De Jonquières, G. , 1998a. Ambitions slimmed for foreign investment pact (8 January 1998). Financ. Times.

De Jonquières, G. , 1998b. World trade: US cool about investment pact (14 July 2003). Financ. Times.

De Jonquières, G. , Kuper, S. , 1998. Push to keep alive effort to draft global investment rules (29 April 1998). Financ. Times.

Denny, C. , 1998. Globalisers run into the buffers (24 March 1998). The Guardian.

Denny, C. , Atkinson, M. , 1998. Britain drops support for MAI (30 October 1998). The Guardian. Dymond, W. , 1999. The MAI: A sad and melancholy tale, in: Hampson, F.O. , Hart, M. , Kudner, M. (Eds.), A big league player? Canada among nations. Oxford University Press, Oxford, pp. 25-53.

European Commission , 1995. A level playing field for direct investment world-wide (COM(95)42 final). Brussels.

European Court of Justice , 1995. Opinion 2/92 (competence of the community or one of its institutions to participate in the Third Revised Decisions of the OECD on national treatment), in: European Court of Justice Reports. European Court of Justice, Luxemburg, pp. I-00521-I00578.

European Court of Justice , 1994. Opinion 1/94 (competence of the community to conclude international agreements concerning services and the protection of intellectual property - Article 228(6) of the EC Treaty), in: European Court of Justice Reports. European Court of Justice, Luxemburg, pp. 1-5267-1-5422.

European Services Forum , 2003a. ESF call for an effective launch of negotiations of a multilateral agreement on trade and investment.

European Services Forum , 2003b. Press release: European services business call upon WTO Members to ensure success in Cancun.

European Voice , 2003. Commission relaxes stance in 'Singapore issues' (27 November 2003). Financial Times, 1998. Bye-bye, MAl? (19 February 1998) 17.

Graham, E. , 2000. Fighting the wrong enemy: Antiglobal activities and multinational enterprises. Institute for International Economics, Washington, DC.

Henderson, D. , 1999. The MAI affair: A story and its lessons. Royal Institute of International Affairs, International Economics Programme, London.

Koutrakos, P. , 2006. EU international relations law: Modern studies in European law. Hart, Oxford.

Kumar, N. , 2003. Investment on WTO agenda: A developing country perspective and way forward for Cancun Ministerial Conference. Econ. Polit. Wkly. 38, 3177-3188.

Lamy, P. , 2003. Cancun's delegates must aim high (8 September 2003). Financ. Times. Lawrence, R.Z. 2006. The Multilateral Agreement on Investment. in: Lawrence, R.Z. , Deverreaux, C. , Watkins, M. . Case Studies in US Trade Negotiations, Volume 1: Making the rules. Institute for International Economics, Washington D.C., 135-186.

Marchand, S. , 1998. La France claque la porte de l'AMI (15 October 1998). Le Figaro. 
Muchlinski, P. , 2000. The rise and fall of the Multilateral Agreement on Investment: Where now? Int. Lawyer 34, 1033-1053.

OECD , 1995a. DAFFE/CMIT/CIME(95)13/FINAL.

OECD , 1995b. Multilateral Agreement on Investment: Check list on substantive issues (DAFFE/MAI(95)1.

OECD , n.d. Multilateral Agreeement on Investment: Documentation from the negotiations [WWW Document]. URL www.oecd.org/daf/mai/.

Schott, J. , 2000. The WTO after Seattle. Institute for International Economics, Washington, DC. Smythe, E. , 1998. The multilateral agreement on investment: A charter of rights for global investors or just another agreement? in: Hampson, F.O. , Appel Molot, M. (Eds.), Leadership and dialogue: Canada among nations. Oxford University Press, Oxford, pp. 239-266.

Thomas, R. , 1997. Fish clog up OECD deal (24 May 1997). The Guardian.

Tieleman, K. , 2000. The failure of the multilateral agreement on investment (MAI) and the absence for a global public policy network [WWW Document]. URL www.gppi.net/fileadmin/gppi/Tieleman_MAI_GPP_Network.pdf (accessed 5.1.13).

Turner, M. , 1998. Delegates determined to fight on to save belingered MAI deal (2 April 1998). Eur. Voice.

UNCTAD, 1999. Lessons from the MAI. UNCTAD Ser. Issues Int. Invest. Agreem. UNCTADITEIITMISC 22.

Woolcock, S. , 2003. The Singapore issues in Cancun: A failed negotiation ploy or a litmus test for global governance? Intereconomics 38, 249-255.

Woolcock, S. , 1993. The European acquis and multilateral trade rules: Are they compatible? J. Common Mark. Stud. 31, 539-558. doi:10.1111/j.1468-5965.1993.tb00479.x

Woolcock, S. , 1990. The Uruguay round: Issues for the European Community and the United States, RIIA discussion paper. Royal Institute of International Affairs, London.

WTO , 2002. WT/WGTI/INF/3.

WTO , 2001. WT/MIN(01)/DEC/1.

WTO , 1999. WTO Briefing note: Ministers start negotiating Seattle Declaration.

WTO , 1997. WT/WGTI/W/1.

\section{Investment disciplines in European Preferential Trade Agreements}

Agence Europe , 2002a. EU/Chile: EU and Chile to intensify rate of negotiations on free trade agreement (26 January 2002).

Agence Europe , 2002b. EU/Chile: Negotiations over a free-trade agreement between the EU and Chile are on right path (2 February 2002).

Agence Europe , 2002c. EU/Chile: Last round of free trade negotiations (7 March 2002).

Agence Europe , 2002d. EU/Chile: Home straight before signing of association agreement (13 April 2002).

Agence Europe , 2002e. EU/Chile: EU and Chile expected to finish negotiations for free-trade agreement on Friday before (26 April 2002).

Agence Europe , 2002f. EU/Chile: EU and Chile conclude negotiations for association and free trade agreement (27 April 2002).

Agence Europe , 2001a. EU/Chile: 6th negotiating round over free-trade agreement clarifies stances on agriculture (5 October 2001).

Agence Europe , 2001b. EU/Chile: On Thursday both parties should come up with joint text, at end of 4th round of negotiations on free-trade agreement (15 March 2001).

Agence Europe , 2001c. EU/Chile: Parties welcome success of the 4th round of negotiation for free trade agreement and open (16 March 2001).

Agence Europe , 2001d. EU/Merocsur/Chile (9 February 2001).

Agence Europe , 2001e. EU/Chile: Liberalisierung innerhalb von zehn Jahren vorgeschlagen (13 July 2001).

Agence Europe , 2001f. EU/Chile: Chilea President announces that two sides intend technically concluding negotiations on (14 September 2001). 
Agence Europe , 2000a. EU/Mexico (20 July 2000).

Agence Europe , 2000b. EU/Chile: Negotiation instruments and procedures toward association agreement are set in place (24 June 2000).

Agence Europe , 2000c. EU/Chile: Third negotiating session for association and free trade agreement begins Monday in Santiago (14 November 2000).

Agence Europe, 1999a. EU/Mexico (22 May 1999).

Agence Europe , 1999b. EU/Mexico (5 March 1999).

Agence Europe, 1999c. EU/Mexico: Free trade (24 July 1999).

Agence Europe , 1999d. EU/Mexico: Eight (and last?) round of negotiations over a free-trade agreement (16 October 1999).

Agence Europe, 1999e. EU/Mexico: Analysis of issues still on the table in trade negotiations (21 October 1999).

Agence Europe, 1999f. EU/Mexico (6 November 1999).

Agence Europe , 1999g. EU/Mexico: Negotiations on free trade agreement are prolonged (13 November 1999).

Agence Europe, 1999h. EU/Chile/Mercosur: EU seeks compromise to allow start of trade negotiations with Chile and the Mercosur (21 September 1999).

Agence Europe , 1999i. EU/Chile/Mercosur: Rahmenabkommen mit Chile tritt in Kraft (20 February 1999).

Agence Europe , 1999j. EU/Mercosur/Chile (4 June 1999).

Agence Europe , 1999k. EU/Chile/Mercosur: EU trade negotiations with Mercosur and Chile on 24 November at ministerial level (18 November 1999).

Agence Europe, 1998a. EU/Mexico: Trade liberalisation (28 April 1998).

Agence Europe, 1998b. EU/Mexico: First joint council meeting on Tuesday 14 July will kick off trade liberalisation negotiations (11 July 1998).

Agence Europe , 1998c. EU/Mexico: Trade liberalisation negotiations to open on 9 November in Mexico City (14 October 1998).

Agence Europe , 1998d. EU/Mexico: Trade negotiations to start on 9 November (7 November 1998).

Agence Europe , 1998e. EU/Mexico: Trade liberalization negotiations could begin in the second half this year (18 February 1998).

Agence Europe , 1997a. EU/Mexico: Member states elaborate global approach to relaunch negotiations of envisaged agreement (15 March 1997).

Agence Europe , 1997b. EU/Mexico: End of negotiations for an interim, global and political agreement (13 June 1997).

Agence Europe , 1997c. EU/Mexico: "Adjustments" to Human Rights clause raise difficul-ties (20 June 1997).

Agence Europe , 1997d. EU/Mexico: Compromise in sight (1 July 1997).

Agence Europe, 1997e. EU/Mexico: Trade liberalisation (9 December 1997).

Agence Europe , 1996a. EU15 disagree on nature and contents of Mexican agreement (14 February 1996).

Agence Europe , 1996b. Spain speaks up for free trade deal with Mexico (22 March 1996). Agence Europe, 1996c. EU/Mexico (21 May 1996).

Agence Europe, 1996d. EU/Mexico (14 May 1996).

Agence Europe, 1996e. EU/Mexico (23 November 1996).

Agence Europe , 1995a. Commission recommends liberalisation of trade with Mexico (10 February 1995).

Agence Europe , 1995b. Council favours rapid start to talks with Mercosur (12 April 1995). Agence Europe , 1995c. Commission outlines aims of agreement with Mexico (26 October 1995).

Baldwin, D. , 2013. Power in international relations, in: Handbook of international relations. Sage Publications, London, pp. 271-297.

Bhagwati, J. , 2008. Termites in the trading system. Oxford University Press, Oxford.

Ceyssens, J. , 2005. Towards a common foreign investment policy? Foreign investment in the European Constitution. Leg. Issues Econ. Integr. 32, 259-291.

Cottier, T. , Elsig, M. , 2011. Governing the World Trade Organization: Past, present and beyond Doha. Cambridge University Press, Cambridge. 
Dür, A. , 2007. EU trade policy as protection for exporters: The agreements with Mexico and Chile. J. Common Mark. Stud. 45, 833-855.

European Commission , 2017. EU trade commissioner in Mexico: "Trade deal possible by year's end" [WWW Document]. URL http://trade.ec.europa.eu/doclib/press/index.cfm?id=1659 (accessed 5.9.17).

European Commission , 2014a. Countries and regions: Mexico [WWW Document]. URL http://ec.europa.eu/trade/policy/countries-and-regions/countries/mexico/ (accessed 5.23.14).

European Commission , 2014b. Countries and regions: Chile [WWW Document]. URL http://ec.europa.eu/trade/policy/countries-and-regions/countries/chile/ (accessed 8.8.14). European Commission , 2006. Minimum platform on investment for EU FTAs: Provisions on establishment in template for a title on "Establishment, trade in services and e-commerce" (D (2006) 9219), Brussels.

European Commission , 2001. Decision No. 2/2001 of the EU-Mexico Joint Council of 27 February 2001. Brussels.

Financial Times, 1997. FT news digest: Talks planed on free trade (11 December 1997). Grossmann, G. , Helpman, E. , 1995. The politics of free trade agreements. Am. Econ. Rev. 85, 667-690.

Harding, G. , 1999. Obstacles remain to EU-Mexico trade deal (7 October 1999). Eur. Voice. Heydon, K. , Woolcock, S. , 2009. The rise of bilateralism: Comparing American, European and Asian approaches to preferential trade agreements. United Nations University Press, Tokyo. Hindelang, S. , 2009. The free movement of capital and foreign direct investment: The scope of protection in EU law. Oxford University Press, Oxford.

Manger, M. , 2009. Investing in protection: The politics of preferential trade agreements between north and south. Cambridge University Press, Cambridge.

Mulligan, M. , 2000. World news: The Americas - Chile and EU in new trade talks (10 April 2000). Financ. Times 3.

Odell, J. , 2000. Negotiating the world economy, Cornell studies in political economy. Cornell University Press, Ithaca, NY.

OECD , 2002. Forty years' experience with the OECD codes of liberalisation of capital movements. OECD, Paris.

Sanahuja, J.A. , 2000. Trade, politics, and democratization: The 1997 global agreement between the European Union and Mexico. J. Interam. Stud. World Aff. 42, 35-62.

Tallberg, J. , 2003. The agenda-shaping powers of the EU Council presidency. J. Eur. Public Policy 10, 1-19.

Woolcock, S. , 2011. European Union economic diplomacy: The role of the EU in external economic relations, Global finance series. Ashgate, Burlington.

Zimmerman, H. , 2007. Realist power Europe? The EU in the negotiations about China's and Russia's WTO accession. J. Common Mark. Stud. 45, 813-832.

\section{The evolution of the EU's legal competences in international investment policy}

Bakker, A. , 1996. The liberalization of capital movements in Europe: The monetary committee and financial integration, 1958-1994, Financial and monetary policy studies. Kluwer Academic Publishing, Dordrecht.

BDI , 2010. Positionspapier: Internationale Investitionsförderverträge: Position der Deutschen Industrie zum Übergang der Kompetenzen auf die Europäische Union.

$\mathrm{CBI}$, n.d. Delivering a more competitive Europe: The CBI's view of the convention on the future of Europe.

Ceyssens, J. , 2005. Towards a common foreign investment policy? Foreign investment in the European Constitution. Leg. Issues Econ. Integr. 32, 259-291.

Comité intergouvernemental créé par la conférence de Messine, 1956. Spaak Report.

Conference of the representatives of the governments of the Member States, 2000a. Progress report on the intergovernmental conference on institutional reform (CONFER 4790/00). Brussels. 
Conference of the representatives of the governments of the Member States, 2000b. Revised summary: Intergovernmental conference on institutional reform (CONFER 4810/00). Brussels. Conference of the representatives of the governments of the Member States, 2000c. Revised summary: Intergovernmental conference on institutional reform (CONFER 4815/00). Brussels. Conference of the representatives of the governments of the Member States , 1996. The European Union today and tomorrow: Adapting the European Union for the benefit of its peoples and preparing it for the future: A general outline for a draft revision of the Treaties (CONF2500/96). Brussels.

Conference of the representatives of the governments of the Member States, 1991a. CONFUP $1788 / 91$.

Conference of the representatives of the governments of the Member States, 1991b. CONF-UP $1792 / 91$.

Conference of the representatives of the governments of the Member States, 1991c. CONFUP $1800 / 91$.

Conference of the representatives of the governments of the Member States, 1991d. CONF-UP $1845 / 91$.

Conference of the representatives of the governments of the Member States, 1991e. CONFUP $1850 / 91$.

Conference of the representatives of the governments of the Member States, 1991f. CONFUP $1862 / 91$.

Conference of the representatives of the governments of the Member States, 1991g. CONFUP-UEM 2017/91.

Cremona, M. , 2003. A policy of bits and pieces? The Common Commercial Policy after nice, in: Dashwood, A. , Hillion, C. , Spencer, J. , Ward, A. (Eds.), Cambridge yearbook of European legal studies (2001-2002). Oxford University Press, Oxford.

Deloche-Gaudez, F. , 2001. The convention on a Charter of Fundamental Rights: A method for the future? Notre Eur. Res. Policy Pap. 15.

Deutscher Bundestag , 1976. Drucksache 7/4882 - Unterrichtung durch die Bundesregierung

"Vorschlag einer Verordnung (EWG) des Rates zur Errichtung einer Europäischen

Ausfuhrbank".

Dimopoulos, A. , 2011. EU foreign investment law. Oxford University Press, Oxford.

Eeckhout, P. , 2011. EU external relations law, 2nd ed., Oxford EU law library. Oxford University Press, Oxford.

European Commission , 2010b. Proposal for a regulation of the European Parliament and the Council establishing transitional arrangements for bilateral investment agreements between Member States and third countries (COM(2010) 344 final). Brussels.

European Commission , 2000. Adapting the institutions to make success of enlargement (COM(2000)34 final). Brussels.

European Commission , 1995a. Report on the operation of the Treaty on the European Union (SEC(95)731 final). Brussels.

European Commission , 1995b. A level playing field for direct investment world-wide (COM(95)42 final). Brussels.

European Commission, 1985. Completing the Internal Market (COM(85) 310). Brussels.

European Convention , 2003a. The European Convention [WWW Document]. URL

http://european-convention.eu.int (accessed 8.10.13).

European Convention , 2003b. Draft articles on external action in the Constitutional Treaty (CONV 685/03). Brussels.

European Convention , 2003c. Proposed amendments to the text of the articles of the Treaty establishing a Constitution for Europe: Common Commercial Policy [WWW Document]. URL http://european-

convention.eu.int/EN/amendments/amendments3dd9.html?content=866\&lang=EN (accessed 8.10.13).

European Convention, 2002a. Discussion paper on external action (CONV 161/02). Brussels.

European Convention, 2002b. Intervention de M. Pascal Lamy, membre de la Commission Européenne, lors de la réunion du groupe de travail VII, le 15 octobre 2002 (working group VII working document 10). Brussels.

European Convention , 2002c. Final report of working group VII on external action (CONV 459/02). Brussels. 
European Court of Justice, 2017. Opinion 2/15 (ECLI/EU/C/2017/376). Luxemburg.

European Court of Justice , 1995. Opinion 2/92 (Competence of the Community or one of its institutions to participate in the Third Revised Decisions of the OECD on national treatment), in: European Court of Justice Reports. European Court of Justice, Luxemburg, pp. I-00521-I00578.

European Court of Justice , 1994. Opinion 1/94 (Competence of the Community to conclude international agreements concerning services and the protection of intellectual property - Article 228(6) of the EC Treaty), in: European Court of Justice Reports. European Court of Justice, Luxemburg, pp. I-5267-I-5422.

European Parliament , 1996a. White paper on the 1996 intergovernmental conference volume II: Germany [WWW Document]. URL www.europarl.europa.eu/igc1996/pos-de_en.htm (accessed 10.1.12).

European Parliament , 1996b. White paper on the 1996 intergovernmental conference volume II: Italy [WWW Document]. URL www.europarl.europa.eu/igc1996/pos-it_en.htm (accessed 10.1.12).

European Parliament , 1996c. White paper on the 1996 intergovernmental conference volume II: Sweden [WWW Document]. URL www.europarl.europa.eu/igc1996/possv_en.htm (accessed 10.1.12).

Hindelang, S. , 2009. The free movement of capital and foreign direct investment: The scope of protection in EU law. Oxford University Press, Oxford.

Johannsen, E.L. , 2009. Die Kompetenz der Europäischen Union für ausländische Direktinvestitionen nach dem Vertrag von Lissabon. Beitr. Zum Transnationalem Wirtsch. Kleine, M. , 2013. Informal governance in the European Union: How governments make international organizations work. Cornell University Press, Ithaca, NY.

Koutrakos, P. , 2006. EU international relations law: Modern studies in European law. Hart, Oxford.

Krajewski, M. , 2005. External trade law and the constitutional treaty: Towards a federal and more democratic common commercial policy? Common Mark. Law Rev. 42, 91-127.

Krenzler, G. , Pitschas, C. , 2005. Die Gemeinsame Handelspolitik nach dem Entwurf des Europäischen Verfassungsvertrags - ein Schritt in die richtige Richtung. Recht Int. Wirtsch. 51, 801-811.

Lamassoure, A. , 2004. Histoire secrète de la Convention Européenne. Albin Michel, Paris. Lavranos, N. , 2013. In defence of member states' BITs gold standard: The regulation 1219/2012 establishing a transitional regime for existing extra-EU BITs: A member state's perspective. Transnatl. Dispute Manag. 10.

Meunier, S. , Nicolaidis, K. , 1999. Who speaks for Europe? The delegation of trade authority in the EU. J. Common Mark. Stud. 37, 477-507.

OECD , 2002. Forty years' experience with the OECD codes of liberalisation of capital movements. OECD, Paris.

Ohler, C. , 2002. Europäische Kapital- und Zahlungsverkehrsfreiheit: Kommentar zu den Artikeln 56 bis 60 EGV, der Geldwäscherichtlinie und Überweisungsrichtlinie. Springer-Verlag, Berlin.

Pierson, P. , 1994. The path to European integration: A historical institutionalist perspective. Harvard University and Russel Sage Foundation, Cambridge, MA.

Poulsen, L. , 2010. The importance of BITs for foreign direct investment and political risk insurance: Revisiting the evidence, in: Sauvant, K. (Ed.), Yearbook of international investment law and policy 2009/2010. Oxford University Press, Oxford, pp. 539-574.

Reinisch, A. , 2014. The EU on the investment path - Quo Vadis Europe? The future of EU BITs and other investment agreements. St. Clara J. Int. Law 12, 111-157.

Scharpf, F. , 1999. Regieren in Europa - Effektiv und demokratisch? Campus, Frankfurt. Scharpf, F. , 1988. The joint decision trap: Lessons from German federalism and European integration. Public Adm. 66, 239-278.

Seidl-Hohenveldern, I. , 1977. Verischerung nichtkommerzieller Risiken und die Europäische Gemeinschaft, Kölner Studien zur Rechtsvereinheitlichung, Band 1. Carl Heymanns Verlag KG, Köln.

Stacey, J. , Rittberger, B. , 2003. Dynamics of formal and informal institutional change in the EU. J. Eur. Public Policy 10, 858-883. doi:10.1080/1350176032000148342 
Tietje, C. , 2009. Gastberitrag - Europa springt ein (29 January 2009). Frankf. Allg. Ztg. UNICE , 2002. Commission White Paper on European Governance: UNICE position. Brussels. Usher, J. , 1992. Capital movements and the treaty on European Union, in: Yearbook of European law. Oxford University Press, Oxford, pp. 35-57.

Vedder, C. , Folz, H.-P. , 1997. A survey of principal decisions of the European court of justice pertaining to international law in 1995. Eur. J. Int. Law 508-532.

\section{Conclusion}

Alschner, W. , 2013. Americanization of the BIT universe: The influence of Friendship, Commerce and Navigation (FCN) treaties on modern investment treaty law. Goettingen J. Int. Law 5, 455-486.

Baetens, F. , 2015. Transatlantic investment treaty protection: A response to Poulsen, Bonnitcha and Yackee , CEPS Special Report. CEPS, Brussels.

Basedow, R. , 2014. Licht in den Schutz der Investoren. Frankfurter Allgemeine Zeitung 20. Bickerton, C. , Hodson, D. , Puetter, U. , 2015. The new intergovernmentalism: European integration in the post-maastricht era. J. Common Mark. Stud. 53, 703-722.

Börzel, T. , 2013. Comparative regionalism: European integration and beyond, in: Carl-snaes, W. , Risse, T. , Simmons, B. (Eds.), Handbook of international relations. Sage, London, pp. 501-530.

Da Conceição, E. , 2010. Who controls whom? Dynamics of power delegation and agency losses in EU trade politics. JCMS: J. Common Mark. Stud. 48, 1107-1126.

doi:10.1111/j.1468-5965.2010.02086.x

Damro, C. , 2007. EU delegation and agency in international trade negotiations: A caution-ary comparison. J. Common Mark. Stud. 45, 883-903.

De Bièvre, D. , Dür, A. , 2004. Delegation and control in European and American trade policy. Manheimer Zentrum für Europäische Sozialforschung Arbeitspapiere 82.

Delreux, T. , Kerremans, B. , 2008. How agents control principals, IIEB Work. Pap. 28.

Dür, A. , 2006. Assessing the EU's role in international trade negotiations. Eur. Poli. Sci. 5, 362-376.

Eckhardt, J. , 2015. Business lobbying and trade governance. Palgrave Macmillan, Basingstoke.

European Commission , 2016. The multilateral investment court project [WWW Document].

European Court of Justice , 2017. Opinion 2/15 (ECLI/EU/C/2017/376). Luxemburg.

Frennhoff Larsén, M. , 2007. Principal-agent analysis with one agent and two principals:

European Union trade negotiations with South Africa . Poli. Policy 35, 440-463.

Gaukrodger, D. , Gordon, K. , 2012. Investor-state dispute settlement: A scoping paper for the investment policy community. OECD Work. Pap. on International Investment 2012/2013. OECD Publishing, Paris.

Hawkins, D. , Nielson, D. , Tierney, M. , Lake, D. (Eds.), 2006. Delegation and agency in international organizations. Cambridge University Press, Cambridge.

Kerremans, B. , 2004. What went wrong in Cancún? A principal-agent view of the EU's rationale towards the Doha Development Round. Eur. Foreign Aff. Rev. 9, 363-393.

Kuijper, P.J. , Pernice, I. , Hindelang, S. , Schwar, M., Reuling, M. , 2014. Investor-State

Dispute Settlement (ISDS) provisions in the EU's international investment agreements.

European Parliament, INTA Committee, Brussels.

Mahoney, J. , Thelen, K. (Eds.), 2010. Explaining institutional change: Ambiguity, agency, and power, 1st ed. Cambridge University Press, Cambridge.

Mestral, A.L.C.D. , Lévesque, C. , 2013. Improving international investment agreements.

Routledge, London.

Meunier, S. , 2005. Trading voices: The European Union in international commercial negotiations. Princeton University Press, Princeton.

Meunier, S. , Nicolaidis, K. , 2006. The European Union as a conflicted trade power. J. Eur. Public Policy 13, 906-925. 
Moravcsik, A. , 1998. The choice for Europe: Social purpose and state power from Messina to Maastricht. Cornell University Press, Ithaca, NY.

Moravcsik, A. , 1991. Negotiating the single European Act: National interests and conventional statecraft in the European Community. Int. Organ. 45, 19-56.

Moravcsik, A. , Schimmelfennig, F. , 2009. European Integration Theory. Liberal intergovernmentalism, in: Wiener, A. , Diez, T. (Eds.),. Oxford University Press, Oxford, pp. 67-87.

Pierson, P. , 2004. Politics in time: History, institutions, and social analysis. Princeton University Press, Princeton.

Pollack, M.A. , 2003. The engines of European integration: Delegation, agency, and agenda setting in the EU. Oxford University Press, Oxford.

Poulsen, L. , Bonnitcha, J. , Yackee, J.W. , 2013. Costs and benefits of an EU-USA investment protection treaty. Department of Business, Innovation and Skills, London.

Reinisch, A. , 2013. The future shape of EU investment agreements. ICSID Review 28, 179-196. doi:10.1093/icsidreview/sit007

Rosamond, B. , 2000. Theories of European integration. Palgrave Macmillan, Basingstoke. Scharpf, F. , 1988. The joint decision trap: Lessons from German federalism and European integration. Public. Adm. 66, 239-278.

Stacey, J. , Rittberger, B. , 2003. Dynamics of formal and informal institutional change in the EU. J. Eur. Public Policy 10, 858-883. doi:10.1080/1350176032000148342

Streeck, W. , Thelen, K.A. (Eds.), 2005. Beyond continuity: Institutional change in advanced political economies. Oxford University Press, Oxford.

Thelen, K. , 2004. How institutions evolve: The political economy of skills in Germany, Britain, the United States, and Japan. Cambridge University Press, Cambridge.

Van Harten, G. , 2007. Investment treaty arbitration and public law. Oxford University Press, Oxford.

Woll, C. , 2008. Firm interests: How governments shape business lobbying on global trade, Cornell studies in political economy. Cornell University Press, Ithaca, NY.

Woll, C. , Artigas, A. , 2007. When trade liberalization turns into regulatory reform: The impact on business-government relations in international trade politics. Regul. Gov. 1, 99-182.

Woolcock, S. , 2010. Trade policy: A further shift towards Brussels, in: Wallace, H. , Pol-lack, M. , Young, A. (Eds.), Policy-making in the European Union. Oxford University Press, Oxford, pp. 382-399.

Young, A. , 2016. Not your parents' trade politics: The transatlantic trade and investment partnership negotiations. Rev. Int. Pol. Econ. 23, 345-378.

Young, A. , 2011. The rise (and fall?) of the EU's performance in the multilateral trading system. J. Eur. Integ. 33, 715-739.

Young, A. , 2002. Extending European cooperation: The European Union and the 'new' international trade agenda. Manchester University Press, Manchester. 